Article

\title{
Provenance and Tectonic Implications of Sedimentary Rocks of the Paleozoic Chiron Basin, Eastern Transbaikalia, Russia, Based on Whole-Rock Geochemistry and Detrital Zircon U-Pb Age and Hf Isotopic Data
}

\author{
Ludmila I. Popeko ${ }^{1}$, Yulia N. Smirnova ${ }^{2}$, Victor A. Zaika ${ }^{2}$, Andrey A. Sorokin ${ }^{2, *}$ and \\ Sergey I. Dril ${ }^{3}$ \\ 1 Kosygin Institute of Tectonics and Geophysics, Far Eastern Branch, Russian Academy of Sciences, 680000 \\ Khabarovsk, Russia; popeko@itig.as.khb.ru \\ 2 Institute of Geology and Nature Management, Far Eastern Branch, Russian Academy of Sciences, 675000 \\ Blagoveshchensk, Russia; smirnova@ascnet.ru (Y.N.S.); zaika_v_a_88@mail.ru (V.A.Z.) \\ 3 Vinogradov Institute of Geochemistry, Siberian Branch, Russian Academy of Sciences, 664033 Irkutsk, \\ Russia; sdril@igc.irk.ru \\ * Correspondence: sorokin@ascnet.ru
}

Received: 20 January 2020; Accepted: 10 March 2020; Published: 19 March 2020

\begin{abstract}
The Chiron Basin extends along the southern periphery of the Siberian Craton and the western margin of the Mongol-Okhotsk Belt. Here, we present whole-rock geochemical data (major and trace elements and $\mathrm{Sm}-\mathrm{Nd}$ isotopes) along with zircon $\mathrm{U}-\mathrm{Pb}$ geochronology and $\mathrm{Lu}-\mathrm{Hf}$ isotopic data from Paleozoic sedimentary rocks within the Chiron Basin to investigate their provenance and tectonic history. $\varepsilon_{\mathrm{Nd}(\mathrm{t})}$ values of the siliciclastics rocks of the Khara-Shibir, Shazagaitui, and Zhipkhoshi formations vary from -17.8 to -6.6 , with corresponding two-stage $\mathrm{Nd}$ model ages $\left(t_{\mathrm{Nd}(\mathrm{C})}\right)$ ranging from 2.56 to $1.65 \mathrm{Ga}$. Detrital zircon grains from these rocks are predominantly Archean, Paleoproterozoic, and Carboniferous-Devonian in age. The data suggest that the southern flank of the Siberian Craton is the only viable source area for Archean and Paleoproterozoic zircon grains with Hf model ages $\left(t_{\mathrm{Hf}(\mathrm{C})}\right)$ of $>2.20 \mathrm{Ga}$. The majority of zircon grains from sandstones from the Khara-Shibir, Shazagaitui, and Zhipkhoshi formations are Devonian-Carboniferous in age. With respect to their Hf model ages, the zircon grains can be subdivided into two groups. The first group of Devonian-Carboniferous zircon grains is characterized by relatively old (mainly Paleoproterozoic) $t_{\mathrm{Hf}(\mathrm{C})}$ model ages of 2.25-1.70 Ga and the source was the southern margin of the Siberian Craton. The second group of Devonian-Carboniferous zircon grains is characterized by significantly younger (mainly Neoproterozoic) $t_{\mathrm{Hf}(\mathrm{C})}$ model ages of $1.35-0.36 \mathrm{Ga}$, which are consistent with a juvenile source, most likely eroded island arcs. Our data, show that sedimentary rocks of the Chiron Basin likely formed in a back-arc basin on the southern periphery of the Siberian Craton facing the Paleozoic Mongol-Okhotsk Ocean.
\end{abstract}

Keywords: detrital zircon; geochronology; provenane analysis, Chiron basin; Siberian Craton; Mongol-Okhotsk Ocean

\section{Introduction}

The Mongol-Okhotsk Belt is one of the major structural elements of East Asia and probably represents the youngest orogenic component within the collage of Central Asian orogenic belts ([1-3] 
and references therein). This NE-SW-oriented belt is located in northern Mongolia and Transbaikalia (Russia) and extends for over $3000 \mathrm{~km}$ from central Mongolia to Uda Bay in the Okhotsk Sea (Figure 1).
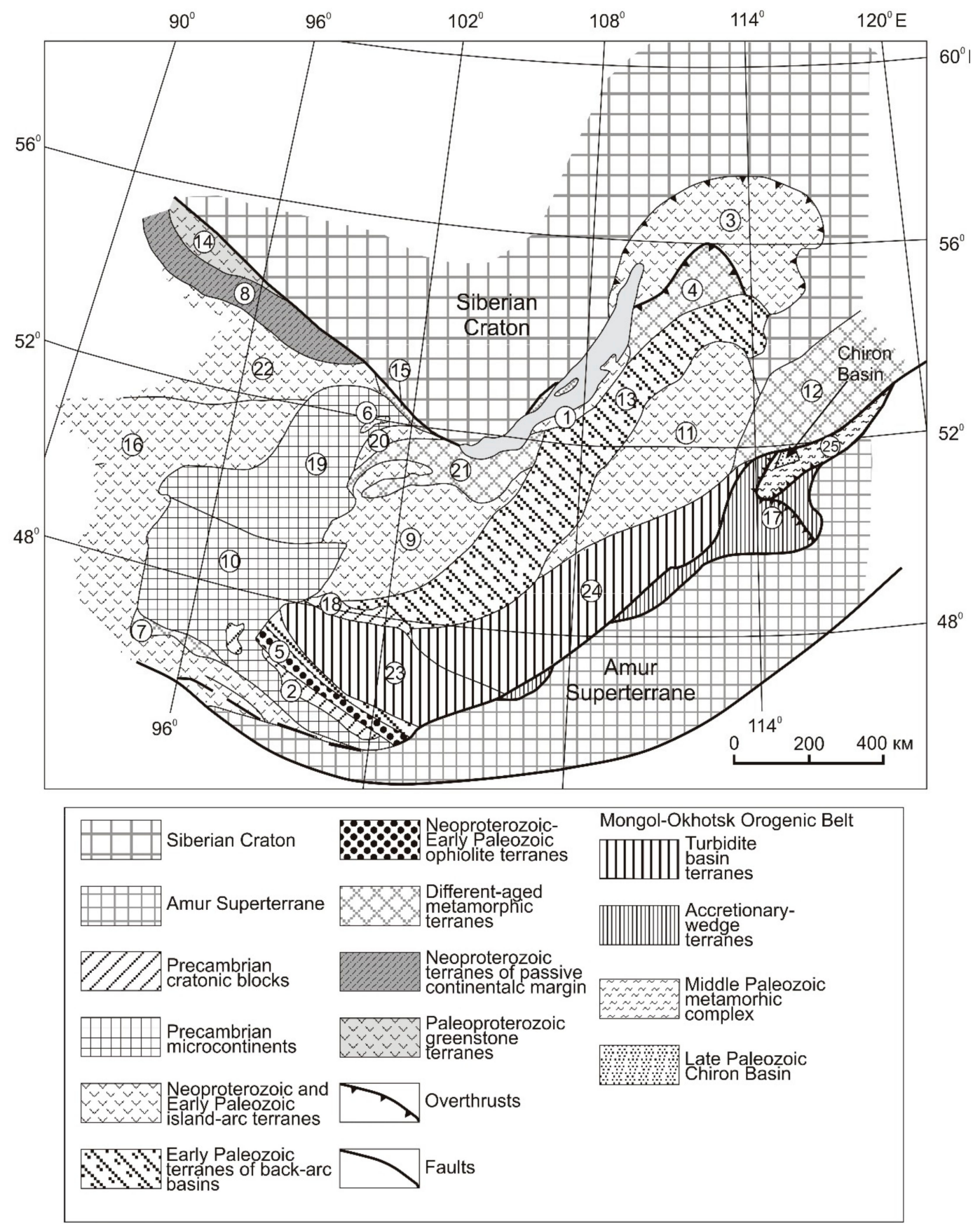

Figure 1. Tectonic scheme showing terranes in the northern segment of the Central Asian Orogenic Belt (compiled after [2,4-10]). Numbers in circles are structures (terranes, microcontinents, cratonic blocks): (1) Anga-Talanchan; (2) Baidarik; (3) Baikal-Muya; (4) Barguzin; (5) Bayan-Khongor; (6) Gargan; (7) Daribi; (8) Derbi; (9) Dzhida; (10) Dzabkhan; (11) Eravna; (12) Western Stanovoi; (13) Ikat; (14) Kan; (15) Kitoikin; (16) Ozernyi; (17) Onon; (18) Tarbagatai; (19) Tuva-Mongol; (20) Tunka; (21) Khamardaban-Olkhon; (22) Khamsarin; (23) Khangai; (24) Khentei; (25) Aga-Borshchovochnyi.

The Mongol-Okhotsk Belt is generally considered ([2,3,11-13] and references therein) to represent a remnant of the Mongol-Okhotsk Ocean, which closed owing to collision between the Siberian Craton and the Amuria Block (superterrane or microcontinent). However, many aspects of the evolution of this structure from ocean to suture zone remain unresolved. 
Most controversial is the geodynamic framework of sedimentary formations and intrusive complexes within the Mongol-Okhotsk Belt, as well as the timing and nature of the accretion and collision. Constraints on the age and composition of sedimentary sequences within the Mongol-Okhotsk Belt and neighboring basins are required to better understand the evolution of the region. In this respect, $\mathrm{U}-\mathrm{Pb}$ and $\mathrm{Lu}-\mathrm{Hf}$ isotopic data from detrital zircon grains from a variety of different stratigraphic ages sedimentary sequences coupled with whole-rock Nd isotopic data are of crucial importance.

Recent geochronological studies have provided tighter constraints on the ages of Paleozoic sedimentary sequences in the western [14-17] and eastern [18-21] parts of the Mongol-Okhotsk Belt. In those studies, subduction zones of different age and polarity have been invoked to explain the evolution of the belt. Furthermore, detailed studies of Jurassic sedimentary rocks of the Mesozoic basins north [22-24] and south [25,26] of the Mongol-Okhotsk Belt have suggested that the Mongol-Okhotsk Ocean closed at the Early-Middle Jurassic boundary.

We performed whole-rock geochemical analyses together with $\mathrm{U}-\mathrm{Pb}$ and $\mathrm{Lu}-\mathrm{Hf}$ isotopic analyses of detrital zircon grains from late Paleozoic sedimentary rocks within the Chiron Basin to provide much-needed information regarding the evolution of the Mongol-Okhotsk Belt. The Chiron Basin is bordered by the southern edge of the Siberian Craton and the Transbaikal segment of the Mongol-Okhotsk Belt. Sedimentary formations within this basin carry important information regarding the geological events that occurred at the periphery of the Siberian Craton during the late Paleozoic associated with the evolution of the Mongol-Okhotsk Ocean.

Geological studies of Eastern Transbaikalia region have led to differing interpretations of the geodynamic nature of the Chiron Basin. Initially, Nagibina [27] identified this basin as a narrow synorogenic basin located at the north of the Mongol-Okhotsk Belt that was confined to the marginal fault zone. This interpretation was supported by Amantov [28], who termed the structures related to the Chiron Basin as "residual orogenic depressions" or "superimposed marginal basins".

Consistent with the current conceptualization of the Mongol-Okhotsk Fold Belt, Parfenov et al. [2,29] interpreted the Chiron Group to represent accumulation of sediments in a forearc basin. However, they did not indicate a magmatic arc adjacent to this forearc basin. Ruzhentsev and Nekrasov [7] ascribed the formation of the Chiron Basin to instability caused by convergence of the Siberian Craton and Argun Continental Massif. A similar interpretation was proposed by Shivokhin et al. [9].

\section{Geological Background}

The Chiron Basin (Figure 1) is located in the northeastern Aga Zone $[7,30]$ and occupies an area of $>500 \mathrm{~km}^{2}$ on the left bank of the lower reaches of the Aga River and within the Chiron River basin. The late Paleozoic Chiron Basin is filled with about 3500-4000 m of unmetamorphosed shallow-marine siliciclastic rocks of the Chiron Group (Figures 2 and 3). Extensive tectonic slices of the Chiron Group also occur to the west and north of the Chiron Basin, as well as in the southern spurs of the Mogoitui Range. Until the mid-1960s, the entire Chiron Group was assigned to the Permian [31]. Later, its age was reassigned to the late Visean to early Permian based on fossil content [32]. The Chiron Group lies unconformably upon metamorphic schists [33] known formerly as the Onon Formation, which was originally assigned a Silurian age by Tolukhonov [31]. However, Amantov [28] and Anashkina et al. [30] suggested a Proterozoic age for these rocks. Recently, metamorphic rocks of the Onon Formation have been regarded as late Paleozoic (middle Paleozoic, according to the Russian stratigraphic nomenclature) and are now termed the Aga-Borshchovochnyi metamorphic complex [9,34] (Figure 3).

The Chiron Group is a polycyclic stratigraphic sequence showing a gradual upward transition from coarse- to fine-grained siliciclastic rocks. Tutkhaltui, Khara-Shibir, Shazagaitui, and Zhipkhoshi formations [33] are assigned to late Visean through to the early Permian [32].

The Tutkhaltui Formation is separated by a sharp angular unconformity from the Aga-Borshchovochnyi metamorphic complex. From bottom to top, this formation consists of the following members [33]: 
1. Conglomerates and sedimentary breccias interbedded with coarse-grained sandstones. Clastic material consists of angular fragments of the metamorphic schists and quartz. Pebbles of felsic volcanic rocks and of granite are rare. The clasts of the sandstones are angular. This member varies from a few meters to $40 \mathrm{~m}$ in thickness.

2. Massive medium- to fine-grained sandstones interbedded with calcareous sandstones and sandy siltstones 1-2 $\mathrm{m}$ thick, and lenses of bioclastic limestone. This member is $45 \mathrm{~m}$ thick.

3. Sandy siltstones gradually passing upwards into massive siltstone. This member is $43 \mathrm{~m}$ thick.

4. Massive medium- to coarse-grained sandstones interbedded with gray siltstones and sedimentary breccias similar in composition to Member (1). This member varies in thickness from 2 to $20 \mathrm{~m}$.

5. Predominantly siltstones with rare thin interlayers of massive medium-grained sandstones. This member is $102 \mathrm{~m}$ thick.

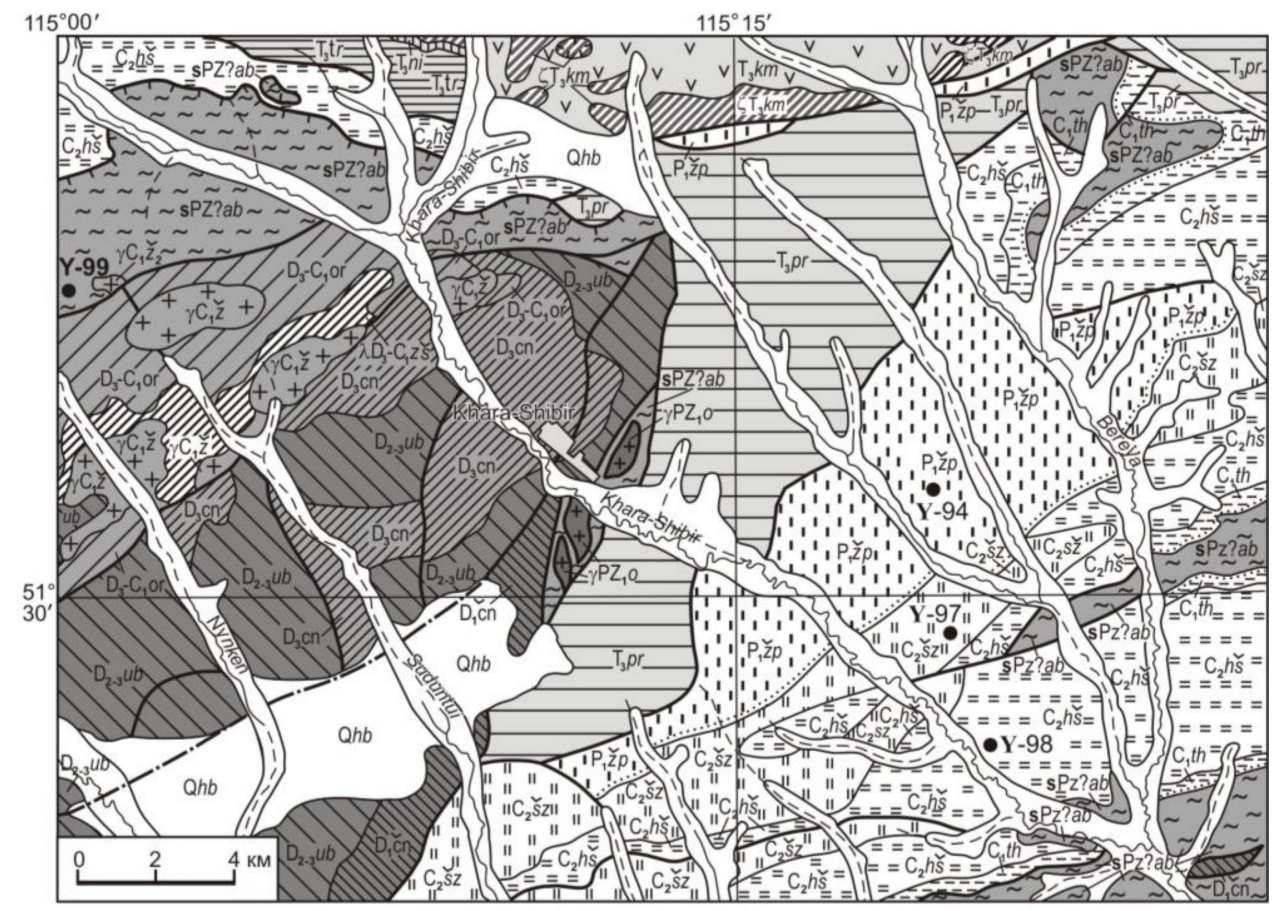

\begin{tabular}{|c|c|c|c|}
\hline \multicolumn{3}{|c|}{$\begin{array}{l}\text { Sedimentary and } \\
\text { metasedimentary formations }\end{array}$} & $\begin{array}{c}\text { Magmatic and } \\
\text { metamorphic complexes }\end{array}$ \\
\hline Qhb & $\begin{array}{l}\text { Kholbon } \\
\text { Formation }\end{array}$ & 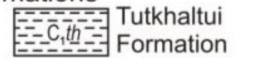 & $\begin{array}{l}\text { Kamenka andesite-dacite } \\
\text { subvolcanic Complex }\end{array}$ \\
\hline $\mathrm{V}^{T_{3} \mathrm{~km} \mathrm{~V}}$ & $\begin{array}{l}\text { Kamenskaya } \\
\text { Formation }\end{array}$ & $\begin{array}{l}\text { Orlovka } \\
\text { Formation }\end{array}$ & $\begin{array}{c}+{ }_{\gamma} C_{1}{ }_{2}+ \\
+\end{array}$ \\
\hline 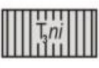 & $\begin{array}{l}\text { Nizhneingodinskaya } \\
\text { Formation }\end{array}$ & $\begin{array}{l}\text { Tsagan-Nor } \\
\text { Das }\end{array}$ & 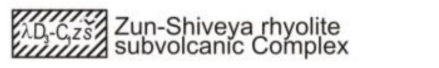 \\
\hline ET,tr豆 & $\begin{array}{l}\text { Tyrgetuy } \\
\text { Formation }\end{array}$ & $\begin{array}{l}\text { Ust'borzja } \\
\text { Formation }\end{array}$ & Olekma granitic Complex \\
\hline $\mathrm{FT}_{3}$ pr & $\begin{array}{l}\text { Pervomay } \\
\text { Formation }\end{array}$ & $\begin{array}{l}\text { Chindant } \\
\text { Formation }\end{array}$ & $\begin{array}{l}\text { Aga-Borshchovochnyi } \\
\text { Metamorphic Complex }\end{array}$ \\
\hline (1, & $\begin{array}{l}\text { Zhipkhoshi } \\
\text { Formation }\end{array}$ & & $\begin{array}{l}\text { 3oundaries: a - conformity, } \\
\text { - unconformity }\end{array}$ \\
\hline${ }_{11}^{\prime \prime} \mathrm{C}_{2} \breve{\mathrm{S} z} z_{11 "}$ & $\begin{array}{l}\text { Shazagaitui } \\
\text { Formation }\end{array}$ & & $\begin{array}{l}\text { aults: a - various kinematics } \\
\text { - trusts }\end{array}$ \\
\hline 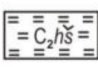 & $\begin{array}{l}\text { Khara-Shibir } \\
\text { Formation }\end{array}$ & & $\begin{array}{l}\text { - Y-94 Sampling locations for zircon } \\
\text { geochronology }\end{array}$ \\
\hline
\end{tabular}

Figure 2. Geological map of the western part of Chiron Basin (after [9,34] and our data). 


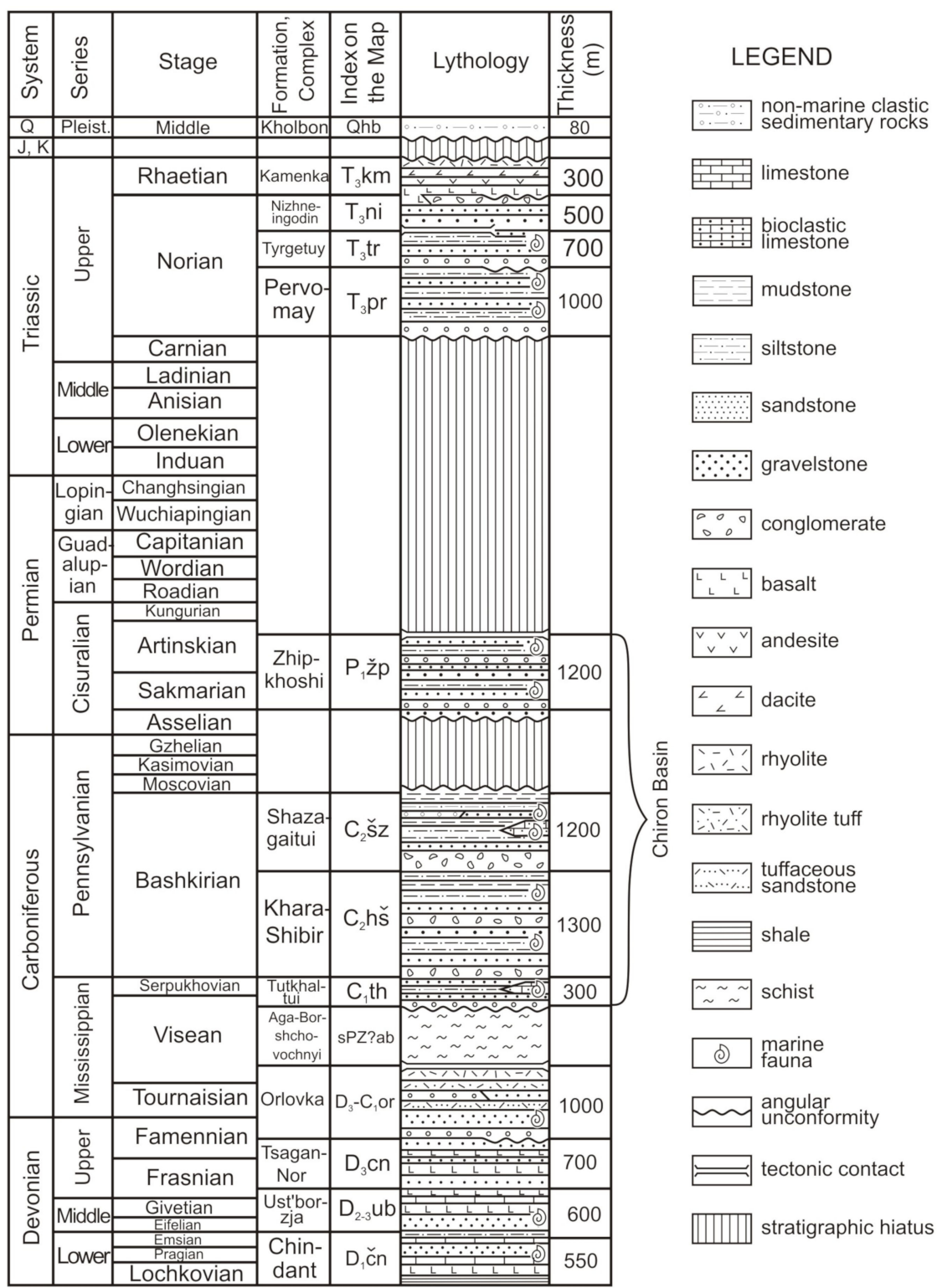

Figure 3. Simplified stratigraphic column for the sedimentary rocks of the Chiron Basin as well as underlying and overlapping formations (modified after [34]).

The Tutkhaltui Formation contains numerous fossilized remains of bryozoans, brachiopods, bivalves, and crinoids [32,33]. Most brachiopod species occur widely in the Kuzbass, Mongolia, Verkhoyansk (Siberia), and Kolyma-Omolon regions of NE Russia [35]. In Mongolia [36] and the Verkhoyansk region [37], ammonoids of the genera Epicanites and Pachylyroceras also occur. These ammonoids are common in late Visean to Serpukhovian sedimentary rocks in Western Europe, the Urals, and North America [38]. On this basis, the Tutkhaltui Formation has been assigned a late Visean to Serpukhovian age.

The Khara-Shibir Formation conformably overlies the Tutkhaltui Formation and comprises two first-order cycles that have the same lithological composition and faunal assemblages. The first-order cycles are considered as Lower and Upper subformations. From bottom to top, the Lower Subformation consists of the following members [33]:

1. A conglomerate member, including two second-order cycles, consisting of medium and fine pebble conglomerates grading upwards into coarse-grained sandstones. Well-rounded pebbles are felsic volcanic rocks $(90 \%)$, granites $(6 \%)$, quartzites $(2 \%)$, sandstones or siltstones $(2 \%)$. 
Sandstones contain angular and poorly sorted clasts. Individual cycles vary in thickness from 20 to $40 \mathrm{~m}$.

2. Alternating massive siltstones and sandy siltstones with flow structures, with gradual transitions between units. This member is $120 \mathrm{~m}$ thick.

3. Alternating fine- to medium-grained massive and bedded sandstones and massive siltstones. Individual layers are 5-20 m thick, the overall thickness of this member is up to $250 \mathrm{~m}$ thick.

The Upper Subformation comprises the following members [33]:

1. Predominantly coarse-grained rocks including second-order cycles consisting (from bottom to top) of medium and fine pebble conglomerates, coarse- to medium-grained sandstones, and sandy siltstones grading into massive siltstones. Individual cycles vary in thickness from 20 to $30 \mathrm{~m}$. Pebbles are dominated by felsic volcanic rocks, together with granites, quartz, quartzites, and gray siltstones. This member is $90 \mathrm{~m}$ thick.

2. Alternating beds of massive medium- to fine-grained sandstones, massive siltstones, and sandy siltstones with gradual transitions between units. Siltstone and sandy siltstone layers are 6-27 m thick and sandstones 1-12 m thick. Single pebbles of felsic volcanic rocks are present at the base of sandy siltstone layers. This member is about $200 \mathrm{~m}$ thick.

3. Mainly siltstones with intercalations of sandstones as thick as $0.2-3 \mathrm{~m}$ irregularly distributed within vertical thickness. The member is up to $280 \mathrm{~m}$ thick.

4. Alternating beds of massive coarse-grained sandstones, medium-grained sandstones, and sandy siltstones with flow texture. Layers vary in thickness from 14 to $40 \mathrm{~m}$. Coarse-grained sandstones contain flattened fragments of siltstone $2-3 \mathrm{~cm}$ in size. The member is $190 \mathrm{~m}$ thick.

The Khara-Shibir Formation is characterized by an extensive assemblage of bryozoans, brachiopods, bivalves, and crinoids [32,33]. Brachiopods in the Khara-Shibir Formation and the underlying Tutkhaltui Formation share a large number of common species. The Khara-Shibir brachiopods are most similar to brachiopods from the Waagenoconcha gigantea Zone (upper part of the Magarsky super-stratohorizon) in the Kolyma-Omolon region [39] and the Sajakella formosa Zone (upper part of the Khatynakh stratohorizon) in the South Verkhoyansk region [35]. Considering the stratigraphic position of the aforementioned analogs of the Khara-Shibir Formation, which overlie layers containing late Visean-Serpukhovian ammonoids and lie below sediments containing late Bashkirian ammonoids, an early Bashkirian age for the Khara-Shibir Formation is implied.

1. The Shazagaitui Formation conformably overlies the Khara-Shibir Formation. From bottom to top, the succession consists of the following members [33]:

2. A conglomerate member comprising second-order cycles consisting of coarse-, medium-, and fine-grained pebble conglomerates grading upward into sandstones and siltstones. Individual cycles vary in thickness from 10 to $70 \mathrm{~m}$. Pebbles comprise felsic volcanic rocks (55\%), granites $(23 \%)$, quartzites $(10 \%)$, granite porphyries $(9 \%)$, sandstones and siltstones $(2 \%)$, and quartz $(1 \%)$.

3. Alternating beds of massive siltstones and sandy siltstones with flow structures, with gradual transitions between units. Interbeds of fine- to medium-grained sandstones $0.5-2 \mathrm{~m}$ in thickness with distinct planar boundaries show no regular pattern. This member is $>500 \mathrm{~m}$ thick.

4. Massive coarse-grained sandstones passing upward into medium- and fine-grained rocks with rare interbeds of dark-gray massive siltstones 1-2 m thick. The thickness of this member exceeds $125 \mathrm{~m}$.

5. Alternating beds of sandy siltstones with massive and flow structures and fine- to medium-grained sandstones, the latter in some places preserving cross-bedding. Intercalations of massive calcareous sandstones and sandy limestones also occur. The thickness of this member varies between 170 and $250 \mathrm{~m}$.

The Shazagaitui Formation contains numerous remains of bryozoans, brachiopods, and crinoids [33]. Most brachiopod species are distributed throughout the Verkhoyansk region, 
(Siberia), and are associated with late Bashkirian ammonoids of the Braneroceras-Gastrioceras and Diabaloceras-Axinolobus zones $[38,40]$. On this basis, the Shazagaitui Formation has been assigned a late Bashkirian age [32]. Overall, the composition, texture, and structure of sedimentary rocks and benthic fauna suggest that the Shazagaitui Formation, as well as the underlying Tutkhaltui and Khara-Shibir formations, formed in a shallow- to moderately deep-marine environment close to the sedimentary source.

The Zhipkhoshi Formation in the central part of the Chiron Basin lies with a stratigraphic hiatus and visible conformity on the Shazagaitui Formation, and angular unconformity the Aga-Borshchovochnyi metamorphic complex in the marginal parts of the basin [33]. The Zhipkhoshi Formation is limited in extent, being restricted to the central part of the Chiron Basin, where the lower portions of the section are exposed. Stratigraphically higher horizons are truncated by a fault that bounds the Chiron Group to the northwest.

From the base upward, the Zhipkhoshi Formation consists of the following members: [33]:

1. Coarse-grained sandstones with intercalations of conglomerate. Pebble-to-boulder conglomerates comprising clasts composed mainly of rhyolite and quartzite and less commonly granitoid. This member varies irregularly in thickness between 90 to $170 \mathrm{~m}$.

2. Siltstones containing plant detritus, fossil wood fragments, megaspores, and nodules formed around the remains of conularia and pelecipods. The thickness is about $300 \mathrm{~m}$.

3. Medium- to fine-grained massive and bedded sandstones with scarce thin siltstone intercalations. The thickness of this member is $400 \mathrm{~m}$.

4. Intercalated fine-grained massive and bedded sandstones and sandy siltstones. Sandstone horizons show cross-bedding and ripple marks. This member is $70 \mathrm{~m}$ thick.

On the basis of the assemblage of brachiopods and bryozoans, the Zhipkhoshi Formation is assigned a Sakmarian to early Artinskian age by analogy with the Verkhoyansk units, (Siberia), which, in addition to the brachiopods similar to the Zhipkhoshi brachiopods, contain ammonoids of the Uraloceras and Paragastrioceras genera [32,35]. The bivalve assemblage suggests a late Asselian to early Artinskian age for the Zhipkhoshi Formation [41]. Thus, the stratigraphic gap between the Shazagaitui and Zhipkhoshi formations spans the Moskovian, Kasimovian, and Gzhelian stages, and probably part of the Asselian stage, a total time span of about 18 Myr. Considering the stratigraphic unconformity between these formations, the inclusion of the Zhipkhoshi Formation within the Chiron Group is controversial $[42,43]$.

The texture of sediments, in combination with the presence of plant detritus, megaspores, fossil wood, and benthic fauna, suggest that rocks of the Zhipkhoshi Formation accumulated in shallow-marine environments, whereas the angular clastic materials provide evidence for a close sedimentary source.

We investigated siliciclastic rocks of the Khara-Shibir, Shazagaitui, and Zhipkhoshi formations, as well as schists of the Aga-Borshchovochnyi metamorphic complex, representing the basement rocks of the Chiron Basin. Sample locations are listed in Table 1 and are shown in Figure 2. 
Table 1. Location and short description of samples.

\begin{tabular}{|c|c|c|c|c|}
\hline Time & Sample No. & GPS $\left[x^{\circ} x^{\prime} x^{\prime \prime}\right]$ & Formation & Petrographic Descriptions \\
\hline \multicolumn{5}{|c|}{ Chiron Basin } \\
\hline $\begin{array}{c}\text { Early } \\
\text { Permian }\end{array}$ & Y-94 & $\begin{array}{l}\text { E, } 115^{\circ} 19^{\prime} 15.3^{\prime \prime} \\
N, 51^{\circ} 31^{\prime} 32.3^{\prime \prime}\end{array}$ & Zhipkhoshi Formation & $\begin{array}{l}\text { Gray sandstone with feldspar }(25 \%) \text {, quartz }(20 \%) \text {, lithic } \\
\text { fragments }(8 \%) \text {, biotite, muscovite and chlorite (up to } \\
1 \%) \text { and with } 0.10-0.18 \mathrm{~mm} \text { grain size. }\end{array}$ \\
\hline $\begin{array}{l}\text { Late } \\
\text { Carboniferous }\end{array}$ & $Y-97$ & $\begin{array}{l}\text { E, } 115^{\circ} 19^{\prime} 43.5^{\prime \prime} \\
N, 51^{\circ} 29^{\prime} 31.5^{\prime \prime}\end{array}$ & Shazagaitui Formation & $\begin{array}{l}\text { Yellowish-gray sandstone with quartz }(40 \%) \text {, feldspar } \\
(30 \%) \text {, lithic fragments }(15 \%) \text {, muscovite }(10 \%) \text { and with } \\
0.10-0.30 \mathrm{~mm} \text { grain size. }\end{array}$ \\
\hline $\begin{array}{l}\text { Late } \\
\text { Carboniferous }\end{array}$ & $Y-98$ & $\begin{array}{l}\mathrm{E}, 115^{\circ} 20^{\prime} 31.3^{\prime \prime} \\
\mathrm{N}, 51^{\circ} 27^{\prime} 56.6^{\prime \prime}\end{array}$ & $\begin{array}{l}\text { Khara-Shibir } \\
\text { Formation }\end{array}$ & $\begin{array}{c}\text { Brownish-yellow sandstone with feldspar }(45 \%) \text {, quartz } \\
(20 \%) \text {, lithic fragments }(20 \%) \text {, biotite }(10 \%) \text {, small } \\
\text { amount muscovite and chlorite (up to } 1 \%) \text { and with } \\
0.10-0.50 \mathrm{~mm} \text { grain size. }\end{array}$ \\
\hline $\begin{array}{c}\text { Late } \\
\text { Paleozoic(?) }\end{array}$ & $Y-99$ & $\begin{array}{l}\mathrm{E}, 115^{\circ} 00^{\prime} 21.9^{\prime \prime} \\
\mathrm{N}, 51^{\circ} 33^{\prime} 33.2^{\prime \prime}\end{array}$ & $\begin{array}{l}\text { Aga-Borshchovochnyi } \\
\text { metamorphic complex }\end{array}$ & $\begin{array}{l}\text { Gray greenschist with quartz ( } 40 \%) \text {, feldspar }(15 \%) \text {, } \\
\text { lithic fragments }(10 \%) \text {, biotite and muscovite }(35 \%) \text {, } \\
\text { small amount chlorite. }\end{array}$ \\
\hline
\end{tabular}

\section{Analytical Methods}

\subsection{Major and Trace Element Analyses}

Chemical compositions of siliciclastic rocks were studied using $\mathrm{X}$-ray fluorescence analysis (XRF) (major elements, Zr) at the Institute of Geology and Nature Management, Far East Branch of the Russian Academy of Sciences, Blagoveshchensk, Russia, and inductively coupled plasma mass spectrometry (ICP-MS) (Cs, Ga, Rb, Sr, Ba, La, Ce, Pr, Nd, Sm, Eu, Gd, Tb, Dy, Ho, Er, Tm, Yb, Lu, Y, Nb, Hf, Ta, $\mathrm{Th}, \mathrm{U}, \mathrm{Pb}$ ) at the Institute of Tectonics and Geophysics, Far East Branch of the Russian Academy of Sciences, Khabarovsk, Russia.

The powdered samples of sedimentary rocks were homogenized for XRF analysis by fusing with a mixture of Li metaborate and tetraborate in a muffle furnace at a temperature of $1050-1100{ }^{\circ} \mathrm{C}$. Measurements were carried out on a 4S Pioneer X-ray spectrometer. Intensities of analytical lines were corrected for the background and for the effects of absorption and secondary fluorescence. For ICP-MS analyses, samples were decomposed with acid mixtures of $\mathrm{HCl}, \mathrm{HNO}_{3}, \mathrm{HF}$, and $\mathrm{HClO}_{4}$. Measurements were performed in a standard regime by Perkin Elmer/Sciex Elan 6100 DRC ICP-MS whose sensitivity over the whole mass scale was calibrated using standard reference solutions that contained all elements to be analyzed in the samples. The relative measurement error for major and minor elements was $3 \%-10 \%$.

\subsection{Sm-Nd Isotopic Analyses}

$\mathrm{Sm}-\mathrm{Nd}$ isotopic analyses were performed at the Collective Enjoyment Center of Isotope Geochemical Investigations, Vinogradov Institute of Geochemistry, Siberian Branch of Russian Academy of Sciences, Irkutsk, Russia. About $100 \mathrm{mg}$ of the whole rock powder was dissolved in a mixture of $\mathrm{HF}, \mathrm{HNO}_{3}$, and $\mathrm{HClO}_{4} . \mathrm{A}^{149} \mathrm{Sm}-{ }^{150} \mathrm{Nd}$ spike solution was added to all samples before dissolution. REE were separated on BioRad AGW50-X8 200-400 mesh resin using conventional cation exchange techniques. Sm and Nd were separated by extraction chromatography with LN-Spec (100-150 mesh) resin [44]. Total blanks during the measurement were 0.1-0.2 ng for Sm and 0.2-0.5 ng for $\mathrm{Nd}$. Isotopic compositions of Sm and Nd were determined on a NEPTUNE Plus Multi-Collector ICP-MS in static mode. The precision $(2 \sigma)$ of $\mathrm{Sm}$ and $\mathrm{Nd}$ contents and ${ }^{147} \mathrm{Sm} /{ }^{144} \mathrm{Nd}$ ratios was $\pm 0.4 \%$ and $\pm 0.003 \%$ for ${ }^{143} \mathrm{Nd} /{ }^{144} \mathrm{Nd}$ ratios. ${ }^{143} \mathrm{Nd} /{ }^{144} \mathrm{Nd}$ ratios were normalized against ${ }^{146} \mathrm{Nd} /{ }^{144} \mathrm{Nd}=0.7219$. The results of the international standards were: 1) JNdi-1 $(n=40),{ }^{143} \mathrm{Nd} /{ }^{144} \mathrm{Nd}=0.512107 \pm 4$ (recommended value, ${ }^{143} \mathrm{Nd} /{ }^{144} \mathrm{Nd}=0.512115 \pm 7$ [45]; 2) BCR-2 $(n=28),{ }^{143} \mathrm{Nd} /{ }^{144} \mathrm{Nd}=0.512630 \pm 14$; $\mathrm{Nd}=28.77 \pm 0.13 \mathrm{ppm} ; \mathrm{Sm}=6.52 \pm 0.03 \mathrm{ppm} ; 3) \mathrm{AGV}-2(n=8)-{ }^{143} \mathrm{Nd} /{ }^{144} \mathrm{Nd}=0.512769 \pm 16$; $\mathrm{Nd}=30.3 \pm 0.02 \mathrm{ppm} ; \mathrm{Sm}=5.42 \pm 0.03 \mathrm{ppm}$.

The $\varepsilon \mathrm{Nd}(\mathrm{t})$ values were calculated using the present-day values for a chondritic uniform reservoir $(\mathrm{CHUR}){ }^{143} \mathrm{Nd} /{ }^{144} \mathrm{Nd}=0.512638$ and ${ }^{147} \mathrm{Sm} /{ }^{144} \mathrm{Nd}=0.1967$ [46]. Whole-rock $\mathrm{t}_{\mathrm{Nd}(\mathrm{DM})}$ mean crustal 
residence ages were calculated using the model of Goldstein and Jacobsen [47] according to which the $\mathrm{Nd}$ isotopic composition of the depleted mantle evolved linearly since $4.56 \mathrm{Ga}$ ago and has a present-day $\varepsilon_{\mathrm{Nd}(0)}$ value of $+10\left({ }^{143} \mathrm{Nd} /{ }^{144} \mathrm{Nd}=0.513151\right.$ and $\left.{ }^{147} \mathrm{Sm} /{ }^{144} \mathrm{Nd}=0.21365\right)$. To account for changes in the ${ }^{147} \mathrm{Sm} /{ }^{144} \mathrm{Nd}$ ratios due to fractionation of accessory minerals during granitoid melt crystallization, two-stage $\mathrm{Nd}$ model ages $\mathrm{t}_{\mathrm{Nd} \text { (DM2-st) }}$ [48] were calculated from the mean crustal ratio ${ }^{147} \mathrm{Sm} /{ }^{144} \mathrm{Nd}=0.12[49]$.

\subsection{Zircon $\mathrm{U}-\mathrm{Pb}$ Dating}

Zircons were isolated using conventional heavy liquid and magnetic techniques before handpicking under a binocular microscope at the Institute of Geology and Nature Management, Far East Branch of the Russian Academy of Sciences, Blagoveshchensk, Russia. Zircon grains were handpicked from concentrates and mounted in a 1" epoxy mount along with multiple fragments of zircon standards (FC, SL2, and R33). The mounts were imaged by BSE using a Hitachi S-3400N scanning electron microscope (SEM) equipped with a Gatan Chroma CL2 detector.

For geochronology, U-Th- $\mathrm{Pb}$ analyses of individual zircon grains were performed by laser ablation-inductively coupled plasma-mass spectrometry (LA-ICP-MS) at the Arizona LaserChron Center, Department of Geosciences, University of Arizona, Tucson, AZ, USA. For details of the analytical procedures, see [50]. The isotopic analyses involved the ablation of zircon using a Photon Machines Analyte G2 excimer laser coupled to a Thermo Element 2 single-collector-ICP-MS, using a drill rate of $\sim 1 \mu \mathrm{m} / \mathrm{s}$, resulting in a final ablation pit depth of $\sim 15 \mu \mathrm{m}$. Grain selection and analysis sites were selected based on CL and BSE images with care taken to avoid inclusions and cracks. Calibration was performed using the FC zircon standard, with a well-established age of $1099.3 \pm 0.3 \mathrm{Ma}$ [51]. The Sri Lanka (SL2) and R33 [52] reference zircons were used as secondary standards for data quality control. Our ${ }^{206} \mathrm{~Pb} /{ }^{238} \mathrm{U}$ and ${ }^{207} \mathrm{~Pb} /{ }^{206} \mathrm{~Pb}$ ages for SL2 zircon were $563.2 \pm 4.8 \mathrm{Ma}$ and $568 \pm 16 \mathrm{Ma}(2 \sigma)$, respectively, which were in good agreement with the ID-TIMS ages reported by Gehrels et al. [53]. Our results yielded weighted mean ${ }^{206} \mathrm{~Pb} /{ }^{238} \mathrm{U}$ and ${ }^{207} \mathrm{~Pb} /{ }^{206} \mathrm{~Pb}$ ages for the R33 zircon of $417 \pm 7 \mathrm{Ma}$ and $415 \pm 8 \mathrm{Ma}$, respectively, which were consistent with the ages of Black et al. [52] and Mattinson [54].

Systematic errors were $0.9 \%$ for ${ }^{206} \mathrm{~Pb} /{ }^{238} \mathrm{U}$ ratios and $0.8 \%$ for ${ }^{206} \mathrm{~Pb} /{ }^{207} \mathrm{~Pb}$ ratios $(2 \sigma)$. U concentrations and $\mathrm{U} / \mathrm{Th}$ ratios were calibrated relative to the SL2 zircon standard and were accurate to $\sim 20 \%$. The concordia U-Pb ages were calculated using Isoplot v. 4.15 [55]. The following data were excluded from the final age calculations: data for which it was not possible to calculate a concordia age and ${ }^{206} \mathrm{~Pb} /{ }^{238} \mathrm{U}$ and ${ }^{207} \mathrm{~Pb} /{ }^{235} \mathrm{U}$ ratios with errors of $>3 \%$, as these exceeded the precision of the LA-ICP-MS method. The peak age was derived from the AgePick program developed by George Gehrels [56].

\subsection{Hf-in-Zircon Isotopes}

Hf isotope analyses were performed using a Nu Instruments high-resolution (HR)-ICP-MS and attached Photon Machines Analyte G2 Excimer laser at the Arizona LaserChron Center. Instrument settings were established first by analysis of $10 \mathrm{ppb}$ solutions of JMC 475 and a Spex Hf solution followed by analysis of $10 \mathrm{ppb}$ solutions containing Spex $\mathrm{Hf}, \mathrm{Yb}$, and $\mathrm{Lu}$. When all solutions yielded ${ }^{176} \mathrm{Hf} /{ }^{177} \mathrm{Hf}$ ratios of $\sim 0.28216$, instrument settings were considered optimized for laser ablation analyses and seven standard zircons (Mud Tank (MT), 91500, Temora (TEM), R33, FC52 (FC), Plesovice (PLES), and SL or (SL-F)) were analyzed. When precision and accuracy were considered acceptable, the unknowns were analyzed using the same acquisition parameters as for the standards.

Laser ablation analyses were conducted using a laser beam diameter of $40 \mu \mathrm{m}$, with the ablation pits located on the U-Pb analysis pits. Each acquisition consisted of one 40 -s integration on backgrounds (on peaks with no laser firing) followed by 60 one-second integrations with the laser firing. Analyses were performed using a typical laser fluence of $\sim 5 \mathrm{~J} / \mathrm{cm}^{2}$, a pulse rate of $7 \mathrm{~Hz}$, and an ablation rate of $\sim 0.8 \mu \mathrm{m} / \mathrm{s}$. Each standard was analyzed once for every $\sim 20$ unknowns. For details of the analytical procedures, see [50]. 
The ${ }^{176} \mathrm{Hf} /{ }^{177} \mathrm{Hf}$ ratio at the time of crystallization is calculated from measurement of present-day ${ }^{176} \mathrm{Hf} /{ }^{177} \mathrm{Hf}$ and ${ }^{176} \mathrm{Lu} /{ }^{177} \mathrm{Hf}$ ratios, using the decay constant of ${ }^{176} \mathrm{Lu}\left(\lambda=1.867 \times 10^{-11}\right)$ from Scherer et al. [57] and Söderlund et al. [58]. Calculation of $\varepsilon_{\mathrm{Hf}(\mathrm{t})}$ values is based on the chondritic ratios of ${ }^{176} \mathrm{Hf} /{ }^{177} \mathrm{Hf}(0.282785)$ and ${ }^{176} \mathrm{Lu} /{ }^{177} \mathrm{Hf}(0.0336)$ given by Bouvier et al. [59]. The mantle model age $\mathrm{t}_{\mathrm{Hf}(\mathrm{DM})}$ was calculated using the measured ${ }^{176} \mathrm{Lu} /{ }^{177} \mathrm{Hf}$ ratio of the zircon, although this only provides a minimum age for the source material of magma from which the zircon crystallized. Therefore, we also calculated the crustal model age $t_{\mathrm{Hf}(\mathrm{C})}$, which assumes that the parental magma of the zircons was produced from average continental crust. ${ }^{176} \mathrm{Lu} /{ }^{177} \mathrm{Hf}$ ratios for average continental crust vary significantly from $\sim 0.001$ to 0.023 [60]. Vervoort and Patchett [60], Amelin and Davis [61] proposed a ${ }^{176} \mathrm{Lu} /{ }^{177} \mathrm{Hf}$ ratio of 0.0093 for the average continental crust, while Griffin et al. [62] recommended a value of 0.015 . However, we considered a value of 0.093 to more realistically reflect the ${ }^{176} \mathrm{Lu} /{ }^{177} \mathrm{Hf}$ ratio of average continental crust, because in some cases the use of the higher ratio results in Hf crustal model ages that are unrealistically higher than the corresponding whole-rock Nd model ages [63-65]. The $t_{\mathrm{Hf}(\mathrm{C})}$ values calculated for ${ }^{176} \mathrm{Lu} /{ }^{177} \mathrm{Hf}$ ratio of 0.015 are given in Supplementary Materials Table S3 for comparison. The depleted mantle line was defined by present-day ${ }^{176} \mathrm{Hf} /{ }^{177} \mathrm{Hf}=0.28325$ and ${ }^{176} \mathrm{Lu} /{ }^{177} \mathrm{Hf}=0.0384$ [62].

\section{Results}

\subsection{Major and Trace Element Geochemistry}

Chemical composition of siliciclastic rocks of the Khara-Shibir, Shazagaitui, and Zhipkhoshi formations are given in Supplementary Materials Table S1.

On a $\log \left(\mathrm{SiO}_{2} / \mathrm{Al}_{2} \mathrm{O}_{3}\right)$ versus $\log \left(\mathrm{Na}_{2} \mathrm{O} / \mathrm{K}_{2} \mathrm{O}\right)$ classification diagram, [66], the siliciclastic rocks from all formations plot as greywacke (Figure 4a). On a $\log \left(\mathrm{SiO}_{2} / \mathrm{Al}_{2} \mathrm{O}_{3}\right)$ versus $\log \left(\mathrm{Fe}_{2} \mathrm{O}_{3} / \mathrm{K}_{2} \mathrm{O}\right)$ classification diagram, [67], the samples plot mostly as arkose and wacke, and rarely as litharenite (Figure 4b). All samples had low values of the Chemical Index of Alteration (CIA $=53-40)$, Chemical Index of Weathering (CIW = 60-42)), and high values for the Weathering Index of Parker (WIP =97-60) and Silica-Titania Index (STI $=90-84)$ (Supplementary Materials Table S1), indicating that rocks in the source area recorded low degrees of weathering. A CIA versus WIP diagram [68] shows that the siliciclastic rocks plot as fresh rocks (Figure 4c).

Sandstones and siltstones from the Khara-Shibir (Figure 5a, Table S1) and Shazagaitui (Figure 5b, Table S1) formations have low to moderate REE contents ( $\Sigma$ REE $=42-229 \mathrm{ppm}$ ) and moderate to weak negative Eu anomalies $\left(\mathrm{Eu} / \mathrm{Eu}^{*}=0.59-0.94\right)$ compared with siliciclastic rocks of the Zhipkhoshi Formation $\left(\Sigma \mathrm{REE}=67-187 \mathrm{ppm}, \mathrm{Eu} / \mathrm{Eu}^{*}=0.64-0.95\right)$ (Figure 5c, Table S1). Trace-element variation diagrams for siliciclastic rocks from the Khara-Shibir (Figure 6a, Table S1) and Shazagaitui (Figure 6b, Table S1) formations show depletions in $\mathrm{U}, \mathrm{Th}, \mathrm{Pb}, \mathrm{Nb}, \mathrm{Ta}, \mathrm{REE}, \mathrm{Sc}, \mathrm{Co}$, and $\mathrm{V}$ relative to upper continental crust. Sandstones and siltstones of the Zhipkhoshi Formation have higher concentrations of these elements (Figure 6c, Table S1).

\subsection{Zircon $\mathrm{U}-\mathrm{Pb}$ Dating}

\subsubsection{Sample Y-99: Greenschist of the Aga-Borshchovochnyi Metamorphic Complex}

Out of 122 detrital zircon grains from sample Y-99, 112 grains yielded concordant ages ranging mainly from c. 2900 to $492 \mathrm{Ma}$ (Figure 7a, Table S2). The major age peaks on probability diagrams are at c. 2512, 1888, 888, 807, 583, $514 \mathrm{Ma}$, and rare zircon grains have concordant Paleoproterozoic and Archean ages. The youngest concordant zircon age is $492 \pm 6 \mathrm{Ma}$ (Late Cambrian).

\subsubsection{Sample Y-98: Sandstone of the Khara-Shibir Formation}

A total of 114 concordant ages were obtained from 130 detrital zircon grains in sample $\mathrm{Y}-98$ (Figure $7 \mathrm{~b}$, Table S2). The estimated ages were mostly Carboniferous and Devonian (age peaks at c. 
353 and $382 \mathrm{Ma}$ ). A single grain had a concordant zircon age of c. $429 \mathrm{Ma}$ (Silurian), and another had a concordant age of c. $506 \mathrm{Ma}$ (Cambrian). The youngest concordant zircon age was $330 \pm 4 \mathrm{Ma}$ (Early Carboniferous).

\subsubsection{Sample Y-97: Sandstone of the Shazagaitui Formation}

Analyses of 116 detrital zircon grains from sample Y-97 yielded 82 concordant ages. Most are Carboniferous (age peak at c. $334 \mathrm{Ma}$ ), Devonian (age peak at c. $379 \mathrm{Ma}$ ), and Paleoproterozoic to early Neoarchean (age peaks at c. 1.88, 2.41, and $2.50 \mathrm{Ga}$ ) (Figure 7c, Table S2).

Individual zircon grains had concordant Archean (c. 2.64 and $2.90 \mathrm{Ga}$ ), Paleoproterozoic (c. 2.13 and $2.07 \mathrm{Ga}$ ), Neoproterozoic (c. 879, 876, and 782, Ma), and Ordovician (c. $472 \mathrm{Ma}$ ). The youngest concordant zircon age was $324 \pm 4 \mathrm{Ma}$ (Early Carboniferous).

\subsubsection{Sample Y-94: Sandstone of the Zhipkhoshi Formation}

Concordant ages, which varied mostly from $313 \mathrm{Ma}$ to $2780 \mathrm{Ma}$, were obtained from 105 detrital zircon grains out of 114 grains analyzed. Main age peaks were at c. 2025, 1928, 1862, 808, 500, 404, 379, and $328 \mathrm{Ma}$ (Figure 7d, Table S2). In addition, rare grains had Neoproterozoic (c. 903, 897, and $861 \mathrm{Ma}$ ) and Archean (c. 2.78, 2.55, 2.52, 2.38, and $2.12 \mathrm{Ga}$ ) concordant ages. The youngest concordant zircon grain had an age of $313 \pm 3 \mathrm{Ma}$ (Late Carboniferous).
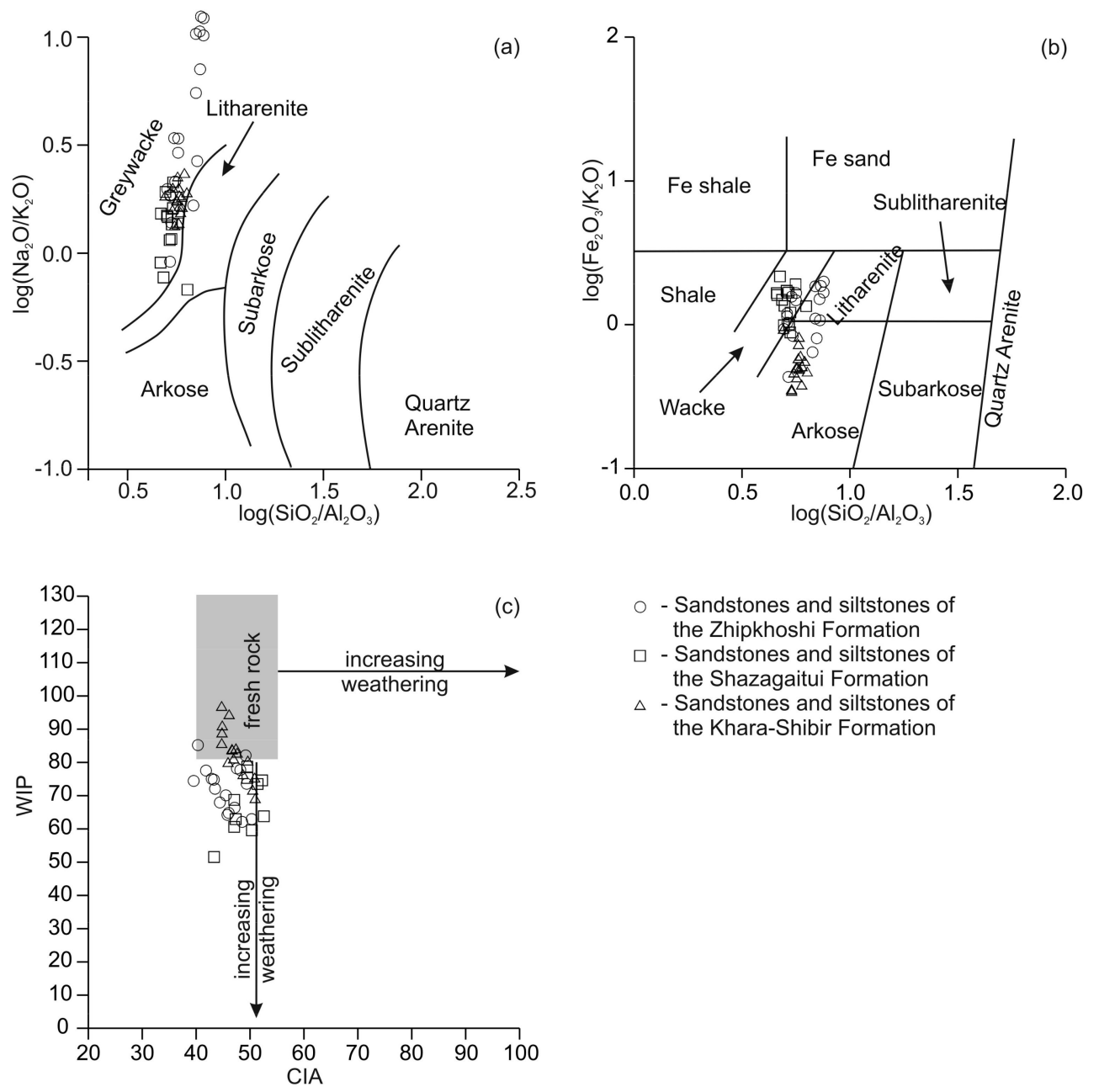

$$
\begin{gathered}
\text { - Sandstones and siltstones of } \\
\text { the Zhipkhoshi Formation } \\
\square \text { - Sandstones and siltstones of } \\
\text { the Shazagaitui Formation } \\
\Delta \text { - Sandstones and siltstones of } \\
\text { the Khara-Shibir Formation }
\end{gathered}
$$

Figure 4. Plots of $\log \left(\mathrm{SiO}_{2} / \mathrm{Al}_{2} \mathrm{O}_{3}\right)$ versus $\log \left(\mathrm{Na}_{2} \mathrm{O} / \mathrm{K}_{2} \mathrm{O}\right)$ after [66] (a), $\log \left(\mathrm{SiO}_{2} / \mathrm{Al}_{2} \mathrm{O}_{3}\right)$ versus $\log \left(\mathrm{Fe}_{2} \mathrm{O}_{3} / \mathrm{K}_{2} \mathrm{O}\right)$ after [67] (b), and CIA versus WIP after [68] (c) for siliciclastic rocks of the Chiron Basin. 

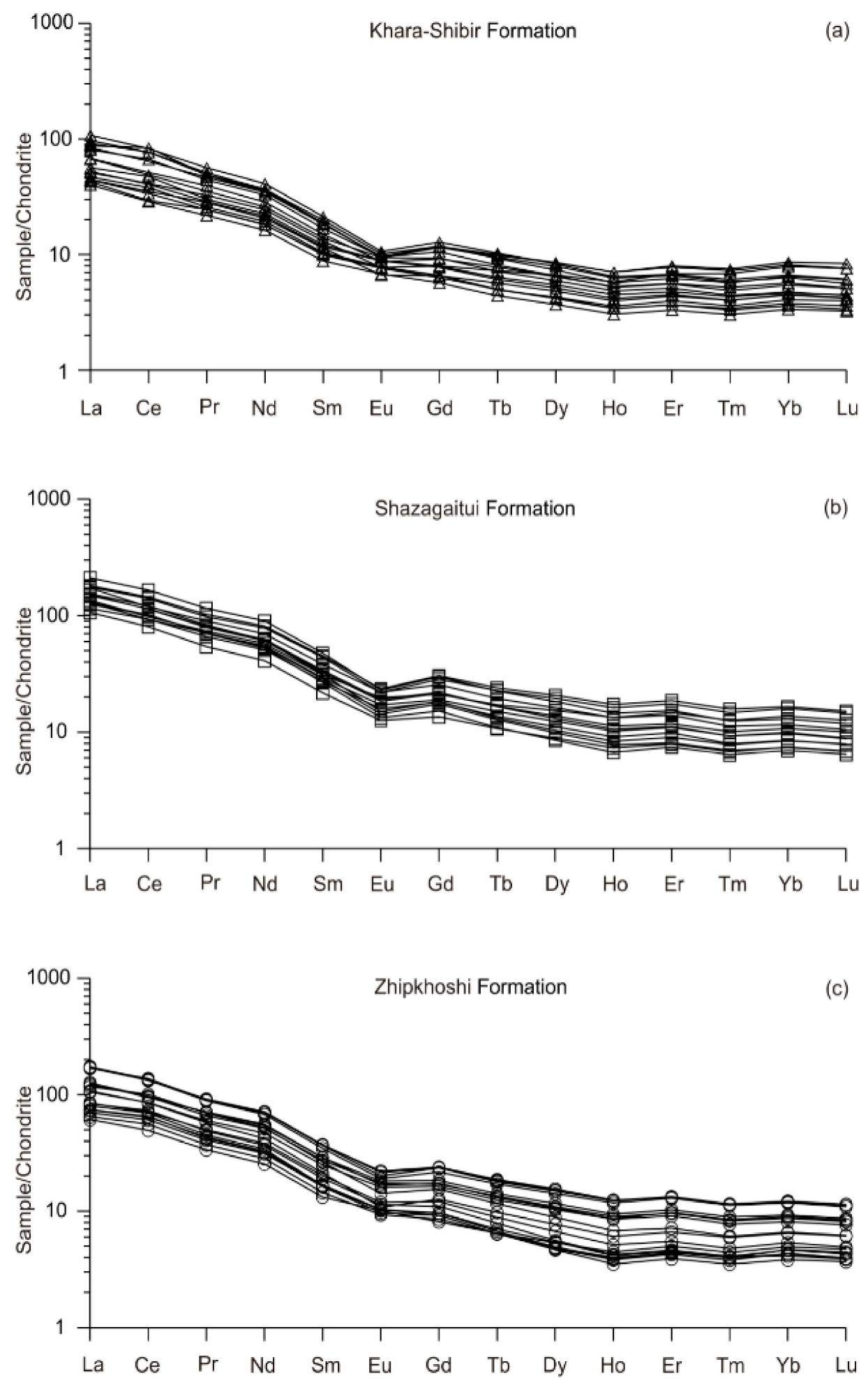

Figure 5. Chondrite-normalized REE patterns for siliciclastic rocks of the Chiron Basin. Chondrite normalizing values are from [69]; (a) Khara-Shibir Formation, (b) Shazagaitui Formation, (c) Zhipkhoshi Formation. 

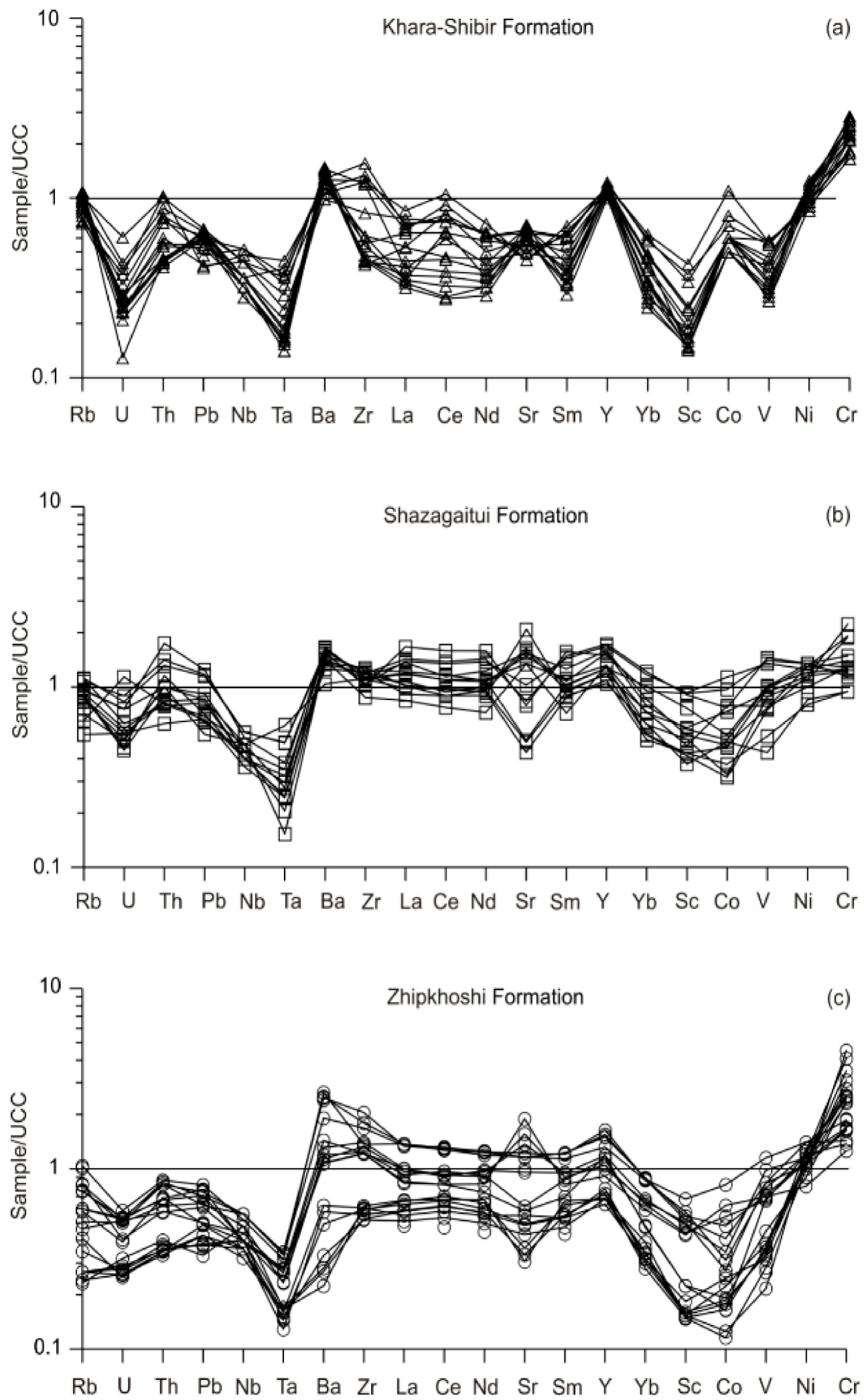

Figure 6. Upper continental crust (UCC)-normalized trace element patterns for siliciclastic rocks of the Chiron Basin. UCC normalizing values are from [49]; (a) Khara-Shibir Formation, (b) Shazagaitui Formation, (c) Zhipkhoshi Formation. 


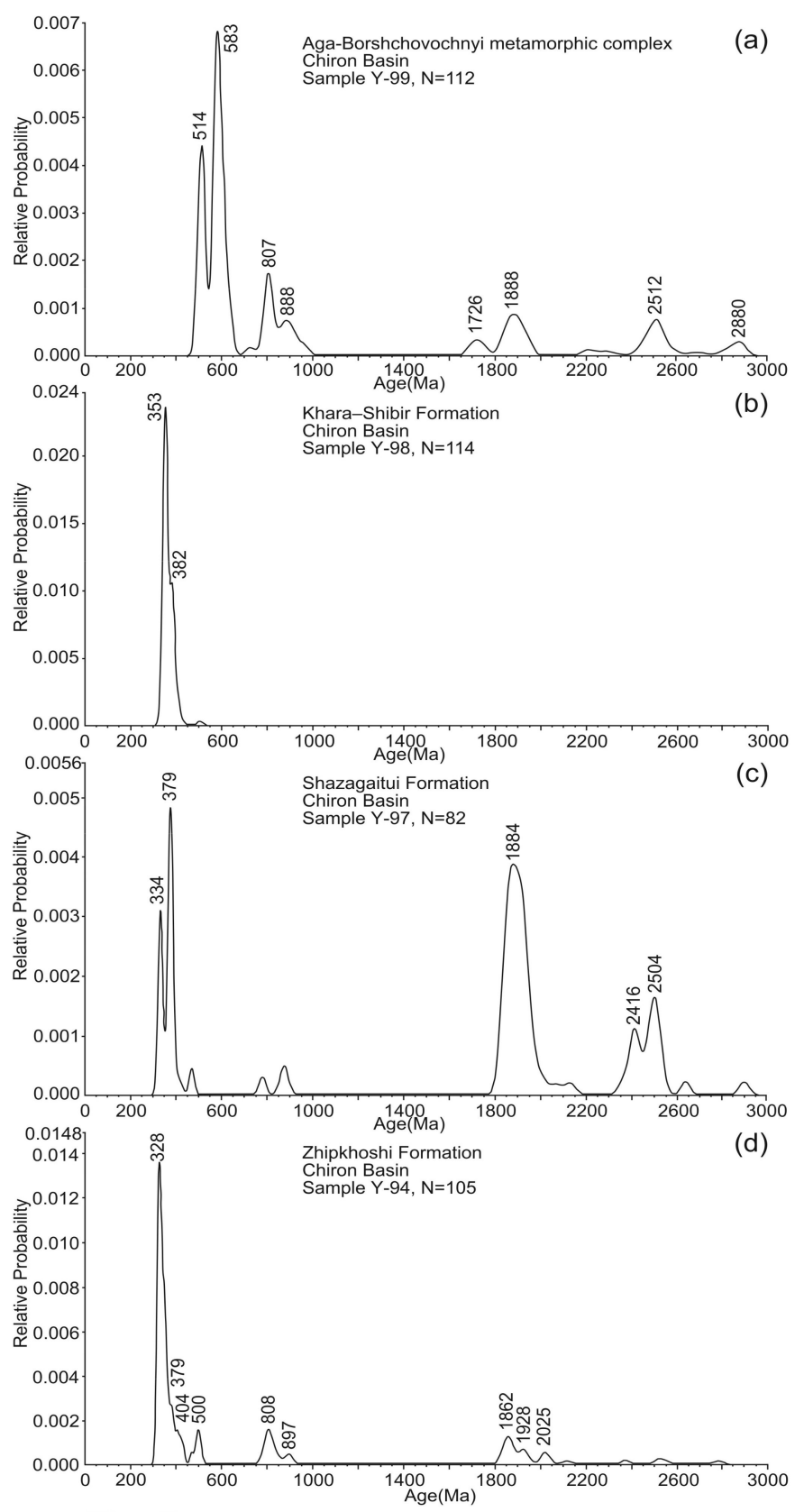

Figure 7. Probability diagrams showing age distributions of detrital zircons from Aga-Borshchovochnyi metamorphic complex and ciliciclastic rocks of the Chiron Basin. Data from Supplementary Table S2; (a) Aga-Borshchovochnyi metamorphic complex, (b) Khara-Shibir Formation, (c) Shazagaitui Formation, (d) Zhipkhoshi Formation.

\subsection{In Situ Zircon Lu-Hf Isotopic Analyses}

The results of Lu-Hf isotope analysis are shown in Figure 8 and listed in Table S3. As follows from Section 4.2 and Figures 7 and 8, major zircon age populations in the Khara-Shibir, Shazagaitui, and Zhipkhoshi formations occurred in the Carboniferous-Devonian, Cambrian, Neoproterozoic, Paleoproterozoic, and Archean, and displayed a wide range of $\mathrm{Hf}$ model ages. The Paleoproterozoic and Archean zircons had $\mathrm{Hf}$ model ages $\left(\mathrm{t}_{\mathrm{Hf}(\mathrm{C})}\right)$ ranging from 2.98 to $2.21 \mathrm{Ga}$. A group of Cambrian and Neoproterozoic zircons had younger $\mathrm{Hf}$ model ages $\left(\mathrm{t}_{\mathrm{Hf}(\mathrm{C})}\right)$ of $1.53-1.00 \mathrm{Ga}$. A more complicated pattern was observed for the Hf isotopic composition of Carboniferous-Devonian zircon grains 
(Figure 8), which had $t_{\mathrm{Hf}(\mathrm{C})}$ values ranging from 1.88 to $0.46 \mathrm{Ga}$ (Table S3). Similar Hf model ages values characterized zircon grains from the Aga-Borshchovochnyi metamorphic complex (Figure 8).

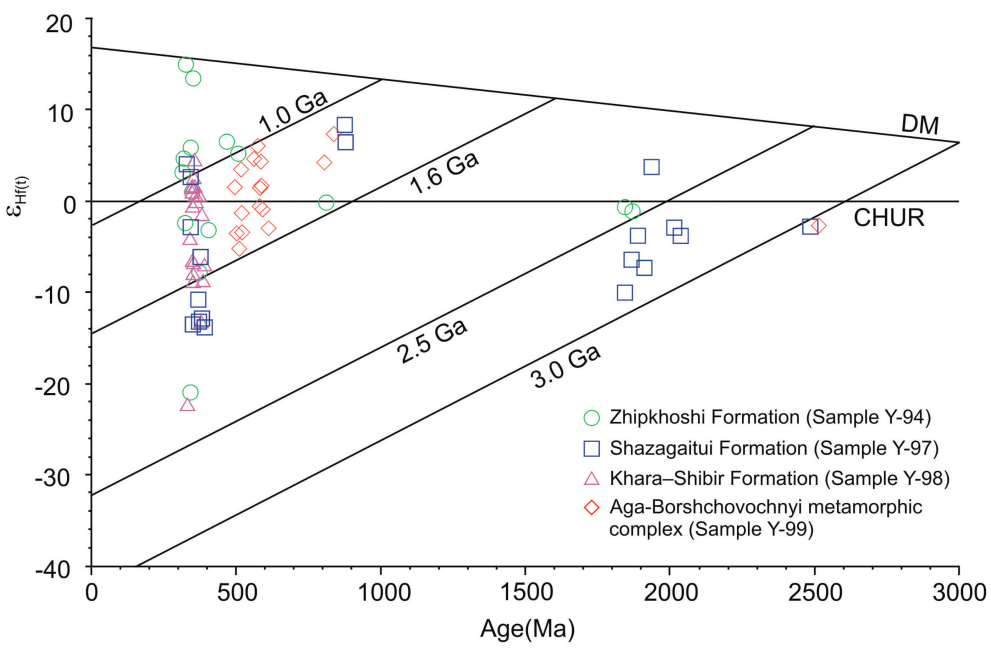

Figure 8. Plots of crystallization age (Ma) versus $\varepsilon_{\mathrm{Hf}(\mathrm{t})}$ for zircon grains from Aga-Borshchovochnyi metamorphic complex and siliciclastic rocks of the Chiron Basin. Data from Table S3.

\subsection{Whole-Rock Nd Isotopic Analyses}

The results of Sm-Nd isotope analysis are presented in Figure 9 and Table $2 .{ }^{147} \mathrm{Sm} /{ }^{144} \mathrm{Nd}$ ratios of siliciclastic rocks from all formations range from 0.0982 to 0.1198 . All samples were characterized by a wide spread in $\varepsilon_{\mathrm{Nd}(\mathrm{t})}$ values from -17.8 to -6.6 , with corresponding two-stage $\mathrm{Nd}$ model ages $\left(t_{\mathrm{Nd}(\mathrm{C})}\right)$ of $2.56-1.65 \mathrm{Ga}$. Sandstones of the Shazagaitui and Zhipkhoshi formations had both the lowest $\varepsilon_{\mathrm{Nd}(\mathrm{t})}$ values $(-17.8$ to -7.3$)$ and the oldest $\mathrm{Nd}$ model ages $\left(\mathrm{t}_{\mathrm{Nd}(\mathrm{C})}=2.56\right.$ to $\left.1.70 \mathrm{Ga}\right)$. Sandstones from the Khara-Shibir Formation had relatively high $\varepsilon_{\mathrm{Nd}(\mathrm{t})}$ values of -8.2 to -6.6 and younger Nd model ages $\left(\mathrm{t}_{\mathrm{Nd}(\mathrm{C})}=1.78-1.65 \mathrm{Ga}\right)$. Schists of the Aga-Borshchovochnyi metamorphic complex had similar isotopic characteristics to those of the Khara-Shibir Formation.

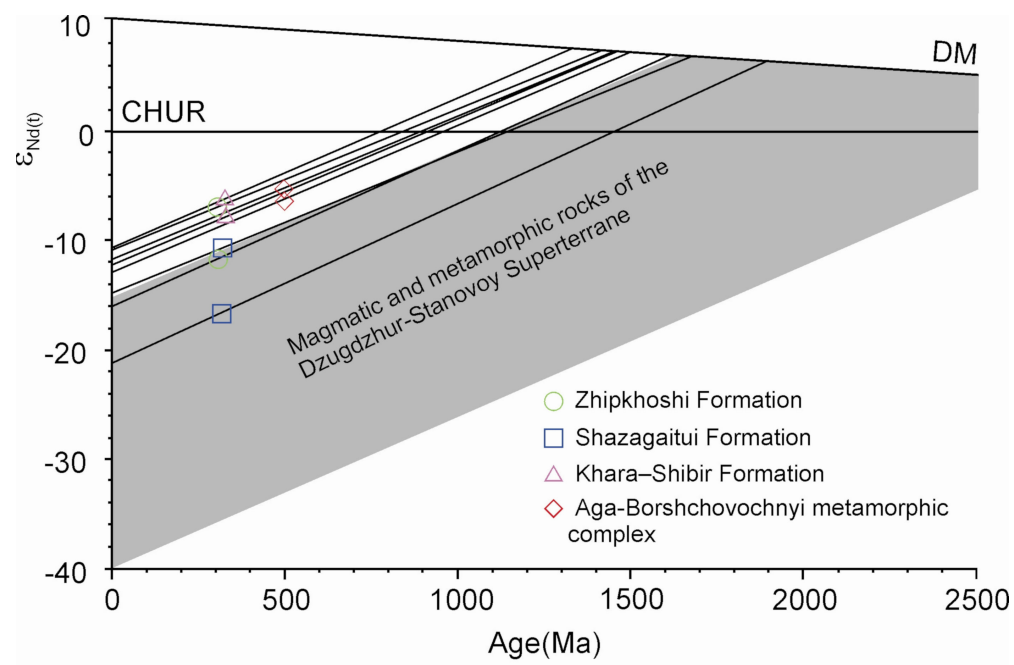

Figure 9. Plots of crystallization age (Ma) versus $\varepsilon_{\mathrm{Nd}(\mathrm{t})}$ values for Aga-Borshchovochnyi metamorphic complex and siliciclastic rocks of the Chiron Basin (black lines, data from Table 2), in comparison with whole-rock compositions of the magmatic and metamorphic rocks of the Dzhugdzhur-Stanovoy Superterrane (grey field, data from [70]). 
Table 2. Whole-rock Sm-Nd isotopic compositions of the rocks of Chiron Basin.

\begin{tabular}{|c|c|c|c|c|c|c|c|c|c|c|c|c|}
\hline Sample & Formation/Complex & Lithology & Age *, Ma & Sm, ppm & $\mathrm{Nd}, \mathrm{ppm}$ & ${ }^{147} \mathrm{Sm} /{ }^{144} \mathrm{Nd}$ & ${ }^{143} \mathrm{Nd} /{ }^{144} \mathrm{Nd}$ & Err $* *$ & $\varepsilon_{\mathrm{Nd}(0)}$ & $\varepsilon_{N d(t)}$ & $t_{\mathrm{Nd}(\mathrm{DM})}$ & $t_{\mathrm{Nd}(\mathrm{C})}$ \\
\hline $\mathrm{Y}-92$ & Khara-Shibir & Sandstone & 330 & 2.08 & 11.76 & 0.10765 & 0.512025 & 16 & -12.0 & -8.2 & 1615 & 1783 \\
\hline$Y-98$ & Khara-Shibir & Sandstone & 330 & 3.24 & 19.93 & 0.09821 & 0.512087 & 2 & -10.7 & -6.6 & 1402 & 1650 \\
\hline Y-96-3 & Shazagaitui & Sandstone & 324 & 5.58 & 31.93 & 0.10637 & 0.511849 & 6 & -15.4 & -11.7 & 1844 & 2064 \\
\hline $\mathrm{Y}-97$ & Shazagaitui & Sandstone & 324 & 3.61 & 21.79 & 0.10006 & 0.511523 & 4 & -21.7 & -17.8 & 2175 & 2565 \\
\hline $\mathrm{Y}-93$ & Zhipkhoshi & Sandstone & 313 & 3.49 & 21.75 & 0.09762 & 0.511813 & 11 & -16.1 & -12.1 & 1752 & 2094 \\
\hline $\mathrm{Y}-94$ & Zhipkhoshi & Sandstone & 313 & 3.85 & 21.94 & 0.10612 & 0.512078 & 2 & -10.9 & -7.3 & 1518 & 1696 \\
\hline $\mathrm{Y}-99$ & Aga-Borshchovochnyi & Greenschist & 492 & 3.65 & 18.41 & 0.11982 & 0.512016 & 2 & -12.1 & -7.3 & 1838 & 1841 \\
\hline $\mathrm{Y}-101$ & Aga-Borshchovochnyi & Greenschist & 492 & 3.40 & 21.01 & 0.09868 & 0.511962 & 6 & -13.2 & -7.0 & 1573 & 1817 \\
\hline
\end{tabular}

* Age of the youngest zircon grains. ${ }^{* *}$ The errors $(2 \sigma)$ refer to the last digits. 


\section{Discussion}

\subsection{Depositional Age of the Formations}

The Aga-Borshchovochnyi metamorphic complex is tentatively assigned a late Paleozoic age (middle Paleozoic, according to the Russian stratigraphic nomenclature) [34], but the youngest concordant zircon age in this complex is $492 \pm 6 \mathrm{Ma}$. We consider that if the Aga-Borshchovochnyi metamorphic schists were indeed late Paleozoic in age, then they would have contained Devonian and, possibly, early Carboniferous zircons, as is the case with the other formations. On this basis, a Cambrian age for the Aga-Borshchovochnyi metamorphic complex cannot be excluded. Alternatively, the complex contains rocks of different ages.

As shown in Section 2, the stratigraphic position of the Khara-Shibir Formation corresponds to the lower Bashkirian stage [32], with the youngest concordant zircon age being $330 \pm 4 \mathrm{Ma}$, corresponding to the Visean-Serpukhovian boundary. On the basis of faunal data, the Shazagaitui Formation is assigned an upper Bashkirian stage [32]. The youngest concordant zircon age found in the sandstone of the Shazagaitui Formation is $324 \pm 4 \mathrm{Ma}$, which essentially corresponds to the Mississippian-Pennsylvanian boundary and does not contradict its biostratigraphic age.

There is an inconsistency between the Sakmarian-early Artinskian [32] or late Asselian-early Artinskian ages [41] proposed for the Zhipkhoshi Formation, as determined from faunal data, and the youngest zircon concordant age of $(313 \pm 3 \mathrm{Ma})$. It looks somewhat odd considering that intense magmatism is recognized both in the Carboniferous and Permian in the region (see Section 5.2 therein).

\subsection{Provenance}

Given the major age populations and variability in isotopic compositions of zircon grains such as $\varepsilon_{\mathrm{Hf}(\mathrm{t})}$ (from -17.8 to -6.6 ) from the Khara-Shibir, Shazagaitui, and Zhipkhoshi formations and whole-rocks two-stage $\mathrm{Hf}$ model ages $\mathrm{t}_{\mathrm{Hf}(\mathrm{C})}$ (from 2.56 to $1.65 \mathrm{Ga}$ ), we can assume that the sources of these zircons varied markedly. As structural analysis of the region attests $[7,9,10,30,71-75]$, the oldest zircon grains in sandstones of the Khara-Shibir, Shazagaitui, and Zhipkhoshi formations, which have Hf model ages $\left(t_{\mathrm{Hf}(\mathrm{C})}\right)$ of $>2.20 \mathrm{Ga}$, could be derived from the southern edge of the Siberian Craton (Figure 1). Igneous and metamorphic complexes that represent fragments of the cratonic basement could be a source for these zircons. Suitable Archean rocks include c. 2.86 Ga tonalite gneiss [70], c. 2.78 Ga gneiss [76], c. 2.83 Ga granite [77], c. 2.62 and 2.52-2.40 Ga granite [78], c. 2.78 Ga metagabbro [79], and c. 2.64 Ga granite gneiss [80]. Moreover, amphibolite-facies metavolcanic and metasedimentary rocks containing zircon grains with ages of 2.90-2.70 Ga could be a source of the Archean zircons.

Paleoproterozoic granitoids are widespread around the periphery of the Siberian craton ([78,81-95] and references therein) and can be divided into eight groups by crystallization age: c. 2.52-2.40, 2.15-2.04, 2.06-2.00, 2.00-1.95, 1.95-1.90, 1.90-1.87, 1.87-1.84, and 1.76-1.71 Ga. Granulite-facies rocks of the Mogocha Formation, which were metamorphosed at $1873 \pm 8 \mathrm{Ma}$ [96], along with Paleoproterozoic ( 1.87 Ga) gabbro-anorthosites [97], could also have been a source for Paleoproterozoic zircon grains within sedimentary rock assemblages of the Chiron Basin.

A small group of Neoproterozoic zircon grains with $t_{\mathrm{Hf}(\mathrm{C})}=1.52-1.16 \mathrm{Ga}$ (Figure 8, Table S3) could be derived from metamorphic rocks of the Ikat Terrane [10] or the Ikat-Bagdarin Zone [75], as well as island-arc complexes of the Kelyan Island Arc. In particular, plagiogranites (971 $\pm 14 \mathrm{Ma}$, [98]), gabbros (939 $\pm 11 \mathrm{Ma}$, [75]), and metabasalts (892 $\pm 16 \mathrm{Ma},[99,100])$ have recently been discovered within this terrane. According to Gordienko et al. $[99,100]$, the island-arc series includes calc-alkaline volcanic rocks with crystallization ages of $837 \pm 11$ and $789 \pm 8 \mathrm{Ma}$ [101]

Zircon grains with Cambrian ages are rare in sedimentary rocks of the Chiron Basin, and we report Hf isotope data from a single grain only (Figure 8, Table S3). This grain has a $\mathrm{t}_{\mathrm{Hf}(\mathrm{C})}$ of $1.00 \mathrm{Ga}$ and could be related to denudation of a differentiated andesite-dacite-rhyolite association assigned to the Caledonian stage of the Uda-Vitim island-arc system, which extends along the southern periphery 
of the Siberian Craton [100,102]. According to Gordienko [102], volcanic rocks have the following crystallization ages: $529 \pm 3 \mathrm{Ma}$ (plagio-rhyolites in the Eravna Area), $516 \pm 5 \mathrm{Ma}$ (quartz porphyry in the Eravna Area), $529 \pm 3$ and $534 \pm 6 \mathrm{Ma}$ (rhyolites in the Oldynda Area), and $530 \pm 26 \mathrm{Ma}$ (dacites in the Kydzhimit Area).

The majority of zircon grains from sandstones of the Khara-Shibir, Shazagaitui, and Zhipkhoshi formations are Devonian-Carboniferous in age. In terms of Hf model ages, the zircon grains can be subdivided into two groups. The first group is characterized by relatively old (mainly Paleoproterozoic) model ages $\left(\mathrm{t}_{\mathrm{Hf}(\mathrm{C})}=2.25-1.7 \mathrm{Ga}\right)$ (Figure 8, Table S3), the sources of which could be the southern fringe of the Siberian Craton, where granitoids of the Olekma Complex have an age of $358 \pm 6 \mathrm{Ma}$ [103]. In addition, granitoids of the Barguzin (or Vitimkan) Complex, which are dated at 330-310 Ma [104,105], could constitute a source of the early Carboniferous zircons. However, this is unlikely as the age of this complex is 297-279 Ma [106]. In addition, there is no certainty regarding the source of Late Devonian zircons. Conceivably, their sources could be intrusions of the Krestovsky and Kruchinin complexes [9], for which there are no reliable age data.

The second group of Devonian-Carboniferous zircons is characterized by significantly younger (mainly Neoproterozoic) model ages $\left(\mathrm{t}_{\mathrm{Hf}(\mathrm{C})}=1.35-0.36 \mathrm{Ga}\right.$ ) (Figure 8, Table S3), suggesting derivation from a source with a significant juvenile component, likely to have been eroded island arcs. Considering the location of the Chiron Basin along the boundary between the southern margin of the Siberian Craton and the western segment of the Mongol-Okhotsk Fold Belt (Figure 1), the sources of such zircons could have been Paleozoic island arcs of the Mongol-Okhotsk Ocean, whose existence is inferred in most geodynamic models $([2,29,107]$ and references therein). Conceivably, a fragment of such an arc is the Zun-Shiveya Complex, which consists of rhyolites, rhyodacites, and granite porphyry, which have tentatively been ascribed as Late Devonian to early Carboniferous in age [9].

In conclusion, it should be noted that like zircon grains from the Khara-Shibir, Shazagaitui, and Zhipkhoshi formations, zircon grains from the Aga-Borshchovochnyi metamorphic complex display a similar range of ages (with the exception of those with Devonian-Carboniferous ages) and have identical isotopic characteristics (Figure 8; Table 2, Table S3). This supports an interpretation in which Archean, Paleoproterozoic, Neoproterozoic, and Cambrian zircons of the Aga-Borshchovochnyi metamorphic complex and Khara-Shibir, Shazagaitui, and Zhipkhoshi formations were derived from the same source.

Sandstones of the Shazagaitui Formation have the oldest model $t_{\mathrm{Nd}(\mathrm{C})}$ ages of $2.65 \mathrm{Ga}$ (Table 2), consistent with the observation that the highest number of Paleoproterozoic and Archean zircons occur in these rocks (Figure 7c). On this basis, we assume that source materials for these rocks must have been derived from the Siberian Craton. Sandstones from the Khara-Shibir and Zhipkhoshi formations have younger model ages $\left(\mathrm{t}_{\mathrm{Nd}(\mathrm{C})}=1.70-1.65 \mathrm{Ga}\right)$ and contain fewer Paleoproterozoic and Archean zircons (Figure $7 \mathrm{~b}, \mathrm{~d}$ ). Considering the Hf isotope data, we suggest at least two sources, one within the Siberian Craton and another that does not represent reworked early Precambrian continental crust, such as the island arcs mentioned above.

\subsection{Tectonic Environments of Sedimentation}

For establishing compositions of source rocks, we used well-known discrimination diagrams based on the values and ratios of major and trace elements. Some of these diagrams are shown in Figure 10. Plots of data from siliciclastic rocks within the Khara-Shibir, Shazagaitui, and Zhipkhoshi formations in $\mathrm{Na}_{2} \mathrm{O}-\mathrm{K}_{2} \mathrm{O}-\mathrm{CaO}$ (Figure $\left.10 \mathrm{a}\right),(\mathrm{CaO}+\mathrm{MgO})-\left(\mathrm{Na}_{2} \mathrm{O}+\mathrm{K}_{2} \mathrm{O}\right)-\left(\mathrm{SiO}_{2} / 10\right)$ (Figure 10b), and $\mathrm{F} 1$ versus $\mathrm{F} 2$ diagrams (Figure 10c) indicate that the source areas were composed mainly of felsic-intermediate igneous rocks. However, plots of the data in $\mathrm{Na}_{2} \mathrm{O}-\mathrm{K}_{2} \mathrm{O}-\mathrm{CaO}$ (Figure 10a) and $\mathrm{Zr} / \mathrm{Sc}$ versus $\mathrm{Th} / \mathrm{Sc}$ ) (Figure 10d) suggest a contribution of recycled material. 

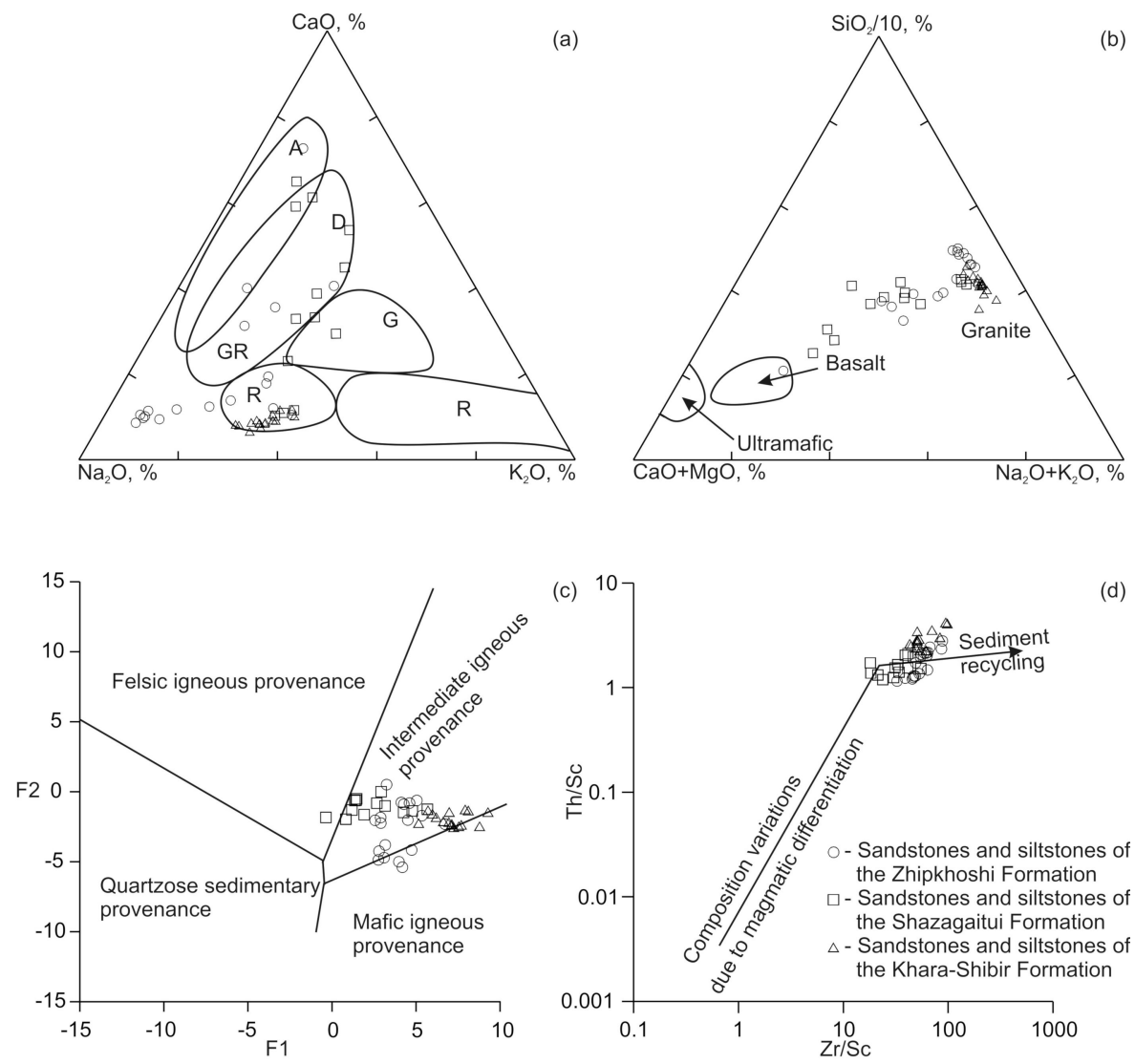

Figure 10. Plots of $\mathrm{Na}_{2} \mathrm{O}-\mathrm{K}_{2} \mathrm{O}-\mathrm{CaO}$ after [108] (a), $(\mathrm{CaO}+\mathrm{MgO})-\left(\mathrm{Na}_{2} \mathrm{O}+\mathrm{K}_{2} \mathrm{O}\right)-\left(\mathrm{SiO}_{2} / 10\right)$ after [49] (b), F1 versus F2 after [109] (c), and $\mathrm{Zr} / \mathrm{Sc}$ versus Th/Sc after [110] (d) for siliciclastic rocks of the Chiron Basin. Fields for the various sources: A-andesites, D-dacites, GR-granodiorites, G-granites, R-recycled sediments.

Additional diagrams were used to constrain the paleotectonic environments of sedimentation. In the bivariate diagrams $\left(\mathrm{Fe}_{2} \mathrm{O}_{3}{ }^{*}+\mathrm{MgO}\right)$ versus $\left(\mathrm{Al}_{2} \mathrm{O}_{3} / \mathrm{SiO}_{2}\right),\left(\mathrm{Fe}_{2} \mathrm{O}_{3}{ }^{*}+\mathrm{MgO}\right)$ versus $\left(\mathrm{Al}_{2} \mathrm{O}_{3} /(\mathrm{CaO}\right.$ $+\mathrm{Na}_{2} \mathrm{O}$ ), $\mathrm{F} 3$ versus $\mathrm{F} 4$, and $\mathrm{SiO}_{2}$ versus $\mathrm{K}_{2} \mathrm{O} / \mathrm{Na}_{2} \mathrm{O}$, data for siliciclastic rock samples of all formations suggest that they accumulated in island-arc and active continental-margin settings (Figure 11a-d). A similar conclusion can be drawn from the ternary diagrams $\left(\mathrm{K}_{2} \mathrm{O}+\mathrm{Na}_{2} \mathrm{O}\right)-\left(\mathrm{TiO}_{2}\right.$ $\left.+\mathrm{Fe}_{2} \mathrm{O}_{3}+\mathrm{MgO}\right)-\left(\mathrm{SiO}_{2} / 20\right)$ and $\mathrm{Co}-\mathrm{Zr} / 10-\mathrm{Th}$ (Figure 11e,f). Thus, the geochemical features of the rocks indicate that the Khara-Shibir, Shazagaitui, and Zhipkhoshi formations were deposited in subduction-related settings.

On the whole, the geochemical characteristics of the siliciclastic rocks (Figure 11), including their wacke/greywacke composition (Figure 4a,b), weak degree of source weathering (Figure 4c), and the presence of interbedded conglomerate and gravelstone (see Section 2), are evidence that sedimentation proceeded in an active tectonic regime. Considering that the clastic sedimentary rocks were sourced from igneous and metamorphic rocks of the Siberian Craton on the one hand, and island arcs on the other, we believe that sedimentation occurred in a backarc-basin setting of the southern periphery of the Siberian Craton facing the Paleozoic Mongol-Okhotsk Ocean. 

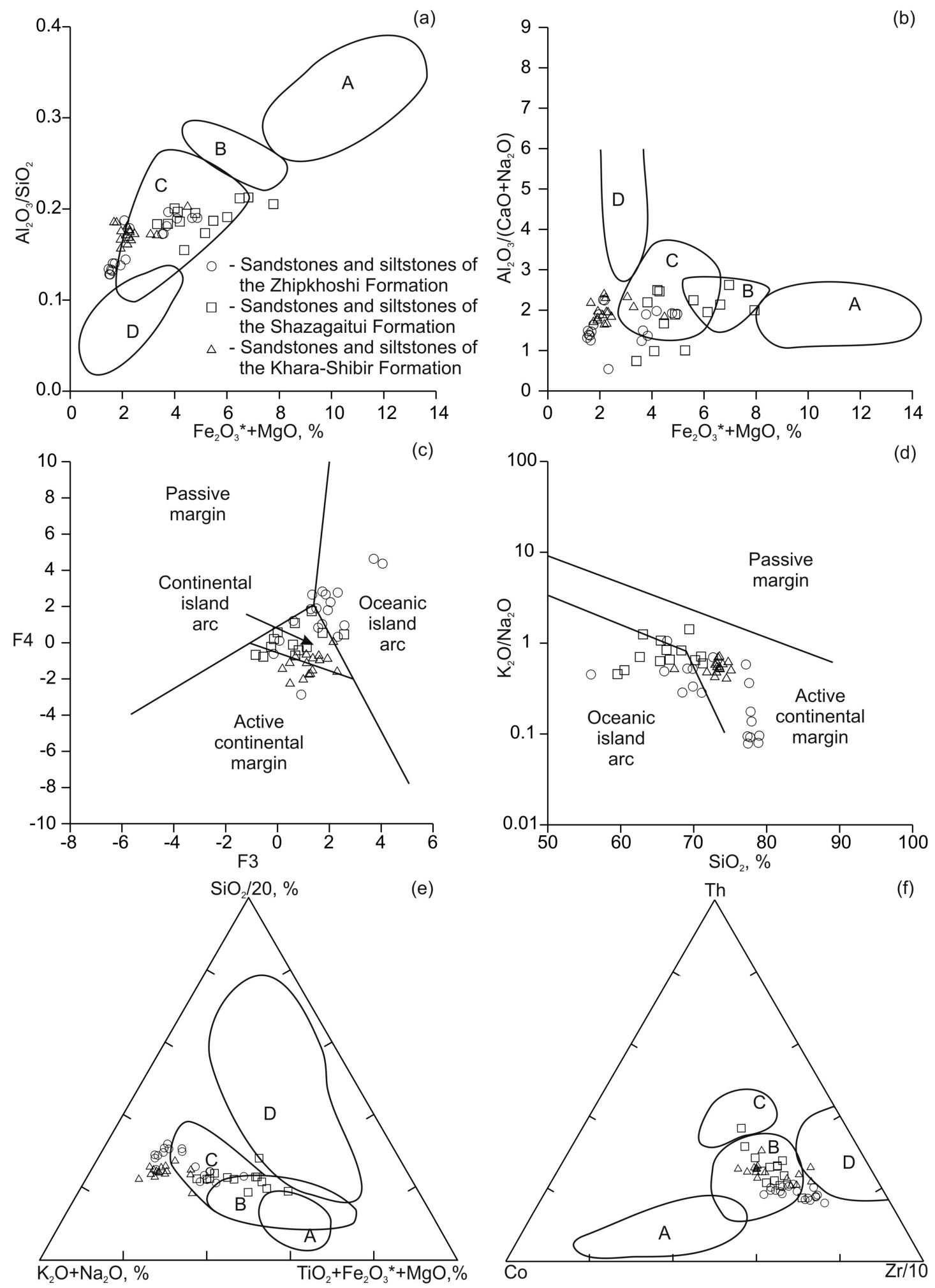

Figure 11. Tectonic discrimination plots of $\mathrm{Fe}_{2} \mathrm{O}_{3}{ }^{*}+\mathrm{MgO}$ versus $\mathrm{Al}_{2} \mathrm{O}_{3} / \mathrm{SiO}_{2}$ after [108] (a), $\mathrm{Fe}_{2} \mathrm{O}_{3}{ }^{*}+$ $\mathrm{MgO}$ versus $\mathrm{Al}_{2} \mathrm{O}_{3} /\left(\mathrm{CaO}+\mathrm{Na}_{2} \mathrm{O}\right)$ after [108] (b), F3 versus $\mathrm{F} 4$ after [109] (c), $\mathrm{SiO}_{2}$ versus $\mathrm{K}_{2} \mathrm{O} / \mathrm{Na}_{2} \mathrm{O}$ after [109] (d), $\left(\mathrm{K}_{2} \mathrm{O}+\mathrm{Na}_{2} \mathrm{O}\right)-\left(\mathrm{TiO}_{2}+\mathrm{Fe}_{2} \mathrm{O}_{3}+\mathrm{MgO}\right)-\left(\mathrm{SiO}_{2} / 20\right)$ after [111] (e), and $\mathrm{Co}-\mathrm{Zr} / 10-\mathrm{Th}$ after [112] (f) for siliciclastic rocks of the Chiron Basin. Fields for the various tectonic settings: A-Oceanic island arc; B-Continental island arc; C-Active continental margin; D—Passive margin. 


\section{Conclusions}

On the basis of our investigation of detrital zircon $\mathrm{U}-\mathrm{Pb}$ and $\mathrm{Hf}$ isotope data and whole-rock $\mathrm{Nd}$ isotope data for sedimentary rocks of the Chiron Basin, we draw the following conclusions.

1. Geochemical characteristics of the siliciclastic rocks, as well as the presence of conglomerate and gravelstone interbeds, suggest that sedimentation occurred in an active tectonic regime.

2. The main source of sedimentary rocks of the Chiron Basin was igneous and metamorphic rocks from the southern periphery of the Siberian Craton. Devonian-Carboniferous zircon grains with relatively young (mainly Neoproterozoic) Hf model ages were derived from island arcs.

3. Combining the new data with regional geological data suggests that sedimentary rocks of the Chiron Basin likely formed in a back arc basin setting on the southern periphery of the Siberian Craton facing the Paleozoic Mongol-Okhotsk Ocean.

Supplementary Materials: The following are available online at http://www.mdpi.com/2075-163X/10/3/279/s1, Table S1. Chemical composition of the sedimentary rocks of the Chiron Basin. Table S2. U-Th-Pb LA-ICP-MS data for zircons from metasedimentary rocks of the Chiron Basin. Table S3. Hf isotopic data for zircons from metasedimentary rocks of the Chiron Basin. References.

Author Contributions: Conceptualization, L.I.P., methodology, Y.N.S., V.A.Z., and S.I.D.; validation, Y.N.S., V.A.Z., A.A.S., and S.I.D., formal analysis, L.I.P., and A.A.S., investigation, L.I.P., Y.N.S., V.A.Z., and A.A.S., writing-review and editing, Y.N.S., V.A.Z., and A.A.S. All authors have read and agreed to the published version of the manuscript.

Funding: The reported study was funded by RFBR according to the research projects number 18-35-20004 and 18-05-00840.

Acknowledgments: The authors thank the staff of the analytical laboratories of the Institute of Geology and Nature Management, Far East Branch, Russian Academy of Sciences (O.G. Medvedeva, V.I. Rozhdestvina, E.S.Sapozhnik, E.V. Ushakova, and E.N. Voropayeva), Institute of Tectonics and Geophysics, Far East Branch, Russian Academy of Sciences (E.M. Golubeva, A.V. Shtareva, V.E. Zazulina), and Arizona LaserChronCenter of the University of Arizona (M. Pecha) for performing the analytical studies.

Conflicts of Interest: The authors declare no conflict of interest.

\section{References}

1. Zonenshain, L.P.; Kuzmin, M.I.; Natapov, L.M. Geology of the USSR: A plate tectonic synthesis. Geodynamics Series. Am. Geophys. Union 1990, 21, 1-242.

2. Parfenov, L.M.; Popeko, L.I.; Tomurtogoo, O. Problems of Tectonics of the Mongol-Okhotsk Orogenic Belt. Geol. Pac. Ocean 2001, 16, 797-830.

3. Wang, W.; Tang, J.; Xu, W.L.; Wang, F. Geochronology and geochemistry of Early Jurassic volcanic rocks in the Erguna Massif, northeast China: Petrogenesis and implications for the tectonic evolution of the Mongol-Okhotsk suture belt. Lithos 2015, 218, 73-86. [CrossRef]

4. Badarch, G.; Cunningham, W.D.; Windley, B.F. A new terrane subdivision for Mongolia: Implications for the Phanerozoic crustal growth of Central Asia. J. Asian Earth Sci. 2002, 21, 87-110. [CrossRef]

5. Belichenko, V.G.; Geletii, N.K.; Barash, I.G. Barguzin microcontinent (Baikal mountain area): The problem of outlining. Russ. Geol. Geophys. 2006, 47, 1035-1045.

6. Volkova, N.I.; Sklyarov, E.V. High-pressure complexes of Central Asian Fold Belt: Geologic setting, geochemistry, and geodynamic implications. Russ. Geol. Geophys. 2007, 48, 109-119. [CrossRef]

7. Ruzhentsev, S.V.; Nekrasov, G.E. Tectonics of the Aga zone, Mongolia-Okhotsk Belt. Geotectonics 2009, 43, 34-50. [CrossRef]

8. Mazukabzov, A.M.; Donskaya, T.V.; Gladkochub, D.P.; Paderin, I.P. The Late paleozoic geodynamics of the West Transbaikalian segment of the Central Asian Fold Belt. Russ. Geol. Geophys. 2010, 51, 482-491. [CrossRef]

9. Shivokhin, E.A.; Ozerskii, A.F.; Kurilenko, A.V.; Raitina, N.I.; Karasev, V.V. State Geological Map of the Russian Federation 1:1000000. In Aldan-Transbaikalian Series, 3rd ed.; Sheet, M-50, Starchenko, V.V., Eds.; VSEGEI: St. Petersburg, Russia, 2010. (In Russian) 
10. Gladkochub, D.P.; Stanevich, A.M.; Mazukabzov, A.M.; Donskaya, T.V.; Pisarevsky, S.A.; Nikoll, G.; Motova, Z.L.; Kornilova, T.A. Early evolution of the Paleoasian ocean: LA-ICP-MS dating of detrital zircon from Late Precambrian sequences of the southern margin of the Siberian craton. Russ. Geol. Geophys. 2013, 54, 1150-1163. [CrossRef]

11. Tomurtogoo, O.; Windley, B.F.; Kröner, A.; Badarch, G.; Liu, D.Y. Zircon age and occurrence of the Adaatsag ophiolite and Muron shear zone, central Mongolia: Constraints on the evolution of the Mongol-Okhotsk Ocean, suture and orogen. J. Geol. Soc. 2005, 162, 125-134. [CrossRef]

12. Khanchuk, A.I.; Didenko, A.N.; Popeko, L.I.; Sorokin, A.A.; Shevchenko, B.F. Structure and Evolution of the Mongol-Okhotsk Orogenic Belt. In The Central Asian Orogenic Belt. Geology, Evolution, Tectonics, and Models; Kröner, A., Ed.; Borntraeger Science Publishers: Stuttgart, Germany, 2015; pp. 211-234.

13. Wang, T.; Tong, Y.; Zhang, L.; Li, S.; Huang, H.; Zhang, J.; Guo, L.; Yang, Q.; Hong, D.; Donskaya, T.; et al. Phanerozoic granitoids in the central and eastern parts of Central Asia and their tectonic significance. J. Asian Earth Sci. 2017, 145, 368-392. [CrossRef]

14. Kelty, T.K.; Yin, A.; Dash, B.; Gehrels, G.E.; Ribeiro, A.E. Detrital-zircon geochronology of Paleozoic sedimentary rocks in the Hangay-Hentey basin, north-central Mongolia: Implications for the tectonic evolution of the Mongol-Okhotsk Ocean in central Asia. Tectonophysics 2008, 451, 290-311. [CrossRef]

15. Bussien, D.; Gombojav, N.; Winkler, W.; Quadt, A. The Mongo-Okhotsk Belt in Mongolia-An appraisal of the geodynamic development by the study of sandstone provenance and detrital zircons. Tectonophysics 2011, 510, 132-150. [CrossRef]

16. Hara, H.; Kurihara, T.; Tsukada, K.; Kon, Y.; Uchino, T.; Suzuki, T.; Takeuchi, M.; Nakane, Y.; Nuramkhaan, M.; Chuluun, M. Provenance and origins of a Late Paleozoic accretionary complex within the Khangai-Khentei belt in the Central Asian Orogenic Belt, central Mongolia. J. Asian Earth Sci. 2013, 75, 141-157. [CrossRef]

17. Ruppen, D.; Knaf, A.; Bussien, D.; Winkler, W.; Chimedtseren, A.; von Quadt, A. Restoring the Silurian to Carboniferous northern active continental margin of the Mongol-Okhotsk Ocean in Mongolia: Hangay-Hentey accretionary wedge and seamount collision. Gondwana Res. 2014, 25, 1517-1524. [CrossRef]

18. Sorokin, A.A.; Kolesnikov, A.A.; Kotov, A.B.; Sorokin, A.P.; Kovach, V.P. Sources of detrital zircons from terrigenous deposits in the Yankan terrane of the Mongolian-Okhotsk mobile belt. Dokl. Earth Sci. 2015, 462, 621-625. [CrossRef]

19. Zaika, V.A.; Sorokin, A.A.; Xu, B.; Kotov, A.B.; Kovach, V.P. Geochemical Features and Sources of Metasedimentary Rocks of the Western Part of the Tukuringra Terrane of the Mongol-Okhotsk Fold Belt. Stratigr. Geol. Correl. 2018, 26, 157-178. [CrossRef]

20. Zaika, V.A.; Sorokin, A.A.; Kovach, V.P.; Sorokin, A.P.; Kotov, A.B. Age and sources of the Lower Mesozoic metasedimentary rocks of the Un'ja-Bom terrane in the Mongol-Okhotsk fold belt: Results of the U-Th-Pb geochronological (LA-ICP-MS) AND Sm-Nd isotope studies. Dokl. Earth Sci. 2019, 484, 115-119. [CrossRef]

21. Zaika, V.A.; Sorokin, A.A. Age and sources of the metasedimentary rocks of the Dzhagda terrane in the Mongol-Okhotsk fold belt: Results of the U-Pb geochronological and Lu-Hf isotope studies. Russ. J. Pac. Geol. 2020, 14, 20-31. [CrossRef]

22. Demonterova, E.I.; Ivanov, A.V.; Mikheeva, E.A.; Arzhannikova, A.V.; Frolov, A.O.; Arzannikov, S.G.; Bryanskiy, N.V.; Pavlova, L.A. Early to Middle Jurassic history of the southern Siberian continent (Transbaikalia) recorded in sediments of the Siberian Craton: Sm-Nd and U-Pb provenance study. Bull. De La Société Géologique De Fr. 2017, 188, 1-29. [CrossRef]

23. Zaika, V.A.; Sorokin, A.A.; Kovach, V.P.; Sorokin, A.P.; Kotov, A.B. Age and sources of detrital zircons from Jurassic conglomerates of the Strelka Depression (northern frame of the Mongol-Okhotsk fold belt). Dokl. Earth Sci. 2019, 485, 372-375. [CrossRef]

24. Zaika, V.A.; Sorokin, A.A.; Kovach, V.P.; Kotov, A.B. Geochemistry of metasedimentary rocks, sources of clastic material and the tectonic nature of the Mesozoic depressions of the northern framing of the eastern part of the Mongol-Okhotsk fold belt. Russ. Geol. Geophys. 2020, 61, 286-302. [CrossRef]

25. He, Z.J.; Li, J.Y.; Mo, S.G.; Sorokin, A.A. Geochemical discriminations of sandstones from the Mohe Foreland basin, northeastern China: Tectonic setting and provenance. Sci. China Ser. D Earth Sci. 2005, 48, 613-621. [CrossRef]

26. Smirnova, Yu.N.; Sorokin, A.A.; Popeko, L.I.; Kotov, A.B.; Kovach, V.P. Geochemistry and provenances of the Jurassic terrigenous rocks of the Upper Amur and Zeya-Dep troughs, eastern Central Asian fold belt. Geochem. Int. 2017, 55, 163-183. [CrossRef] 
27. Nagibina, M.S. Stratigraphy and Formations of the Mongol-Okhotsk Belt; VINITI: Moscow, Russia, $1969 ;$ p. 399. (In Russian)

28. Amantov, V.A. Tectonics and Formations of Transbaikalia and Northern Mongolia. Tr. Vsegei 1975, $231,223$. (In Russian)

29. Parfenov, L.M.; Berzin, N.A.; Badarch, G.; Belichenko, V.G.; Bulgatov, A.N.; Dril, S.I.; Khanchuk, A.I.; Kirillova, G.L.; Kuz'min, M.I.; Nokleberg, W.J.; et al. Tectonic and Metallogenic Model for Northeast Asia; USGS Professional Paper 1765; Nokleberg, W.J., Ed.; U.S. Geological Survey: Reston, VA, USA, 2010; pp. 1-55.

30. Anashkina, K.K.; Butin, K.S.; Enikeev, F.I.; Kinyakin, A.V.; Krasnov, V.P.; Krivenko, V.A.; Oleksiv, B.I.; Pinaeva, T.A.; Rutshtein, I.G.; Semenov, V.N.; et al. Geological Structure of the Chita Region: Explanatory Notes to the Geological Map 1:500000. Chita 1997, 239. (In Russian)

31. Tulokhonov, M.I. Geological Map of the USSR 1:200000; East Transbaikalian SeriesVostochno-Zabaikal'Skaya SeriesSheet M-50-II; Gosgeoltekhizdat: Moscow, Russia, 1962. (In Russian)

32. Kurilenko, A.V.; Kotlyar, G.V.; Kul'kov, N.P. (Eds.) Atlas of Fauna and Flora of the Paleozoic-Mesozoic of the Transbaikalia; Nauka: Novosibirsk, Russia, 2002; p. 714. (In Russian)

33. Kotlyar, G.V.; Popeko, L.I. Upper Paleozoic biostratigraphy, bryozoa, and brachiopods of Transbaikalia. Zap. Zabaikal'sk. Fil. Geogr. O-Va SSSR 1967, 28, 323. (In Russian)

34. Rutshtein, I.G.; Bogach, G.I.; Enikeev, F.I.; Vaviliv, D.E. State Geological Map of the Russian Federation 1:200000; Eastern Transbaikalian Series; Sheet M-50-II; VSEGEI: St. Petersburg, Russia, 2019. (In Russian)

35. Kletz, A.G. Upper Paleozoic of the Marginal Seas of Angarida; Yolkin, E.A., Ed.; Geo: Novosibirsk, Russia, 2005; p. 441. (In Russian)

36. Afanasjeva, G.A. Carboniferous Biostratigraphy, fauna and flora of Deng-Nuru Range, South Mongolia, The joint Soviet-Mongolian Paleontological Expedition 21. Nauka Mosc. 1983, 104. (In Russian)

37. Abramov, B.S.; Grigorjeva, A.D. Biostratigraphy and brachiopods of Lower Carboniferous of the Verkhoyansk region. Nauka Mosc. 1986, 193. (In Russian)

38. Ruzhentsev, V.E. Ammonoids and Carboniferous chronostratigraphy of Eastern Siberia. Paleontol. J. 1975, 2, $28-45$.

39. Ganelin, V.G.; Tschernjak, G.E. Marine basins of Northeast Asia. In The Carboniferous of the World, 3rd ed; International Union of Geological Sciences Publication: The Former USSR, Mongolia, Middle Eastern Platform, Afghanistan; Iran, 1996; Volume 33, pp. 207-434.

40. Sobolev, E.S.; Budnikov, I.V.; Klets, A.G. Late Bashkirian ammonoids and nautiloids from the Western Verkhoyansk Region. J. Paleontol. 1998, 32, 447-461.

41. Byakov, A.S. A new Permian bivalve zonal scale of Northeastern Asia. Article 2: Correlation problems. Russ. J. Pac. Geol. 2013, 7, 1-15. [CrossRef]

42. Murphy, M.A.; Salvador, A. International Stratigraphic Guide-An abridged version. Episodes 1999, 22, 255-271. [CrossRef]

43. Zhamoida, A.I. Stratigraphic Code of Russia, 3rd ed.; VSEGEI Press: Petersburg, Russia, 2006.

44. Yang, Y.; Chu, Z.-Y.; Wu, F.-Y.; Xie, L.-W.; Yang, J.-Y. Precise and accurate determination of Sm, Nd concentrations and $\mathrm{Nd}$ isotopic compositions in geological samples by MC-ICP-MS. J. Anal. At. Spectrom. 2011, 26, 1237-1244. [CrossRef]

45. Tanaka, T.; Togashi, S.; Kamioka, H.; Amakawa, H.; Kagami, H.; Hamamoto, T.; Yuhara, M.; Orihashi, Y.; Yoneda, S.; Shimizu, H.; et al. JNdi-1: A neodymiumisotopic reference in consistency with La Jolla neodymium. Chem. Geol. 2000, 168, 279-281. [CrossRef]

46. Jacobsen, S.; Wasseburg, G. Sm-Nd isotopic evolution of chondrites and achondrites. II. Earth Planet. Sci. Lett. 1984, 67, 137-150. [CrossRef]

47. Goldstein, S.J.; Jacobsen, S.B. Nd and Sr isotopic systematic of rivers water suspended material: Implications for crustal evolution. Earth Planet. Sci. Lett. 1988, 87, 249-265. [CrossRef]

48. Keto, L.; Jacobsen, S. Nd and Sr isotopic variations of Early Paleozoic oceans. Earth Planet. Sci. Lett. 1987, 84, 27-41. [CrossRef]

49. Taylor, S.R.; McLennan, S.M. The Continental Crust: Its Composition and Evolution; Blackwell Scientific Publication: London, UK, 1985; p. 384.

50. LaserChron Center. Department of Geosciences, University of Arizona, Tucson, AZ, USA. Available online: www.laserchron.org (accessed on 18 March 2020). 
51. Paces, J.B.; Miller, J.D. Precise U-Pb ages of Duluth Complex and related mafic intrusions, northeastern Minnesota: Geochronological insights to physical, petrogenic, paleomagnetic, and tectonomagmatic processes associated with the 1.1. Ga Midcontinent Rift System. J. Geophys. Res. 1993, 98, 13997-14013. [CrossRef]

52. Black, L.P.; Kamo, S.L.; Allen, C.M.; Davis, D.W.; Aleinikoff, J.N.; Valley, J.W.; Mundil, R.; Campbell, I.H.; Korsch, R.J.; Williams, I.S.; et al. Improved 206Pb/238U microprobe geochronology by the monitoring of trace-element-related matrix effect; SHRIMP, ID-TIMS, ELA-ICP-MS and oxygen isotope documentation for a series of zircon standards. Chem. Geol. 2004, 205, 15-140. [CrossRef]

53. Gehrels, G.E.; Valencia, V.; Ruiz, J. Enhanced precision, accuracy, efficiency, and spatial resolution of U-Pb ages by laser ablation-multicollector-inductively coupled plasma-mass spectrometry. Geochem. Geophys. Geosystems 2008, 9, 1-13. [CrossRef]

54. Mattinson, J.M. Analysis of the relative decay constants of ${ }^{235} \mathrm{U}$ and ${ }^{238} \mathrm{U}$ by multi-step CA-TIMS measurements of closed system natural zircon samples. Chem. Geol. 2010, 275, 186-198. [CrossRef]

55. Ludwig, K.R. User's Manual for a Geochronological Toolkit for Microsoft Excel; Berkeley Geochronology Center Special Publication: Berkeley, CA, USA, 2008; pp. 1-75.

56. Gehrels, G.E. AgePick. 2007. Available online: https://sites.google.com/a/laserchron.org/laserchron/home/ (accessed on 9 January 2020).

57. Scherer, E.; Münker, C.; Mezger, K. Calibration of the Lutetium-Hafnium Clock. Science 2001, 293, 683-687. [CrossRef] [PubMed]

58. Söderlund, U.; Patchett, P.J.; Vervoort, J.D.; Isachsen, C.E. The ${ }^{176} \mathrm{Lu}$ decay constant determined by Lu-Hf and U-Pb isotope systematics of Precambrian mafic intrusions. Earth Planet. Sci. Lett. 2004, 219, 311-324. [CrossRef]

59. Bouvier, A.; Vervoort, J.D.; Patchett, J. The Lu-Hf and Sm-Nd isotopic composition of CHUR: Constraints from unequilibrated chondrites and implications for the bulk composition of terrestrial planets. Earth Planet. Sci. Lett. 2008, 273, 48-57. [CrossRef]

60. Vervoort, J.D.; Patchett, P.J. Behavior of hafnium and neodymium isotopes in the crust: Constraints from Precambrian crustally derived granites. Geochim. Cosmochim. Acta 1996, 60, 3717-3723. [CrossRef]

61. Amelin, Y.; Davis, W.J. Geochemical test for branching decay of 176Lu. Geochim. Cosmochim. Acta 2005, 69, 465-473. [CrossRef]

62. Griffin, W.L.; Belousova, E.A.; Shee, S.R.; Pearson, N.J.; O'Reilly, S.Y. Archean crustal evolution in the northern Yilgarn Craton: U-Pb and Hf-isotope evidence from detrital zircons. Precambrian Res. 2004, 131, 231-282. [CrossRef]

63. Kovach, V.P.; Degtyarev, K.E.; Tretyakov, A.A.; Kotov, A.B.; Tolmacheva, E.V.; Wang, K.L.; Chung, S.L.; Lee, H.Y.; Jahn, B.M. Sources and provenance of the Neoproterozoic placer deposits of the northern Kazakhstan: Implication for continental growth of the western Central Asian Orogenic Belt. Gondwana Res. 2017, 47, 28-43. [CrossRef]

64. Kröner, A.; Alexeiev, D.V.; Hegner, E.; Rojas-Agramonte, Y.; Corsini, M.; Chao, Y.; Wong, J.; Windley, B.F.; Liu, D.; Tretyakov, A.A. Zircon and muscovite ages, geochemistry, and Nd-Hf isotopes for the Aktyuz metamorphic terrane: Evidence for an Early Ordovician collisional belt in the northern Tianshan of Kyrgyzstan. Gondwana Res. 2012, 21, 901-927. [CrossRef]

65. Kröner, A.; Alexeiev, D.V.; Rojas-Agramonte, Y.; Hegner, E.; Wong, J.; Xia, X.; Belousova, E.; Mikolaichuk, A.; Seltmann, R.; Liu, D.; et al. Mesoproterozoic (Grenville-age) terranes in the Kyrgyz North Tianshan: Zircon ages and Nd-Hf isotopic constraints on the origin and evolution of basement blocks in the southern Central Asian Orogen. Gondwana Res. 2013, 23, 272-295. [CrossRef]

66. Pettijohn, F.J.; Potter, R.; Siever, R. Sand and Sandstone; Springer: Heidelberg, Germany, 1972; p. 535.

67. Herron, M.M. Geochemical classification of terrigenous sands and shales from core or log data. J. Sediment. Petrol. 1988, 58, 820-829.

68. Bahlburg, H.; Dobrzinski, N. A Review of the Chemical Index of Alteration (CIA) and Its Application to the Study of Neoproterozoic Glacial Deposits and Climate Transitions. In The Geological Record of Neoproterozoic Glaciations; Memoir 36; Arnaud, E., Halverson, G.P., ShieldsZhou, G.A., Eds.; Geological Society: London, UK, 2011; pp. 81-92.

69. McDonough, W.F.; Sun, S.S. The composition of the Earth. Chem. Geol. 1995, 120, 223-253. [CrossRef] 
70. Velikoslavinskii, S.D.; Kotov, A.B.; Kovach, V.P.; Tolmacheva, E.V.; Sorokin, A.A.; Sal'nikova, E.B.; Larin, A.M.; Zagornaya, N.Yu.; Wang, K.L.; Chung, S.-L. Age and tectonic position of the Stanovoi metamorphic complex in the eastern part of the Central Asian Foldbelt. Geotectonics 2017, 51, 341-352. [CrossRef]

71. Donskaya, T.V.; Sal'nikova, E.B.; Sklyarov, E.V.; Gladkochub, D.P.; Mazukabzov, A.M.; Kovach, V.P.; Yakovleva, S.Z.; Berezhnaya, N.G. Early Proterozoic postcollision magmatism at the southern flank of the Siberian Craton: New geochronological data and geodynamic implications. Dokl. Earth Sci. 2002, 383, 125-128.

72. Donskaya, T.V.; Gladkochub, D.P.; Kovach, V.P.; Mazukabzov, A.M. Petrogenesis of Early Proterozoic postcollisional granitoids in the southern Siberian Craton. Petrology 2005, 13, 229-252.

73. Larin, A.M.; Sal'nikova, E.B.; Kotov, A.B.; Makar'ev, L.B.; Yakovleva, S.Z.; Kovach, V.P. Early Proterozoic syn-and postcollision granites in the northern part of the Baikal Fold Area. Stratigr. Geol. Correl. 2006, 14, 463-474. [CrossRef]

74. Rytsk, E.Y.; Kovach, V.P.; Yarmolyuk, V.V.; Kovalenko, V.I.; Bogomolov, E.S.; Kotov, A.B. Isotopic structure and evolution of the continental crust in the East Transbaikalian segment of the Central Asian Foldbelt. Geotectonics 2011, 45, 349-377. [CrossRef]

75. Ruzhentsev, S.V.; Minina, O.R.; Nekrasov, G.E.; Aristov, V.A.; Golionko, B.G.; Doronina, N.A.; Lykhin, D.A. The Baikal-Vitim Fold System: Structure and geodynamic evolution. Geotectonics 2012, 46, 87-110. [CrossRef]

76. Nutman, A.P.; Cherneshev, I.V.; Baadsgaard, H.; Smelov, A.P. The Aldan Shield of Siberia, USSR: The age of its Archean components and evidence for widespread reworking in the mid-Proterozoic. Precambrian Res. 1992, 54, 195-210. [CrossRef]

77. Larin, A.M.; Sal'nikova, E.B.; Kotov, A.B.; Glebovitsky, V.A.; Kovach, V.P.; Berezhnaya, N.G.; Yakovleva, S.Z.; Tolkachev, M.D. Late Archean granitoids of the dambukinskiř block of the Dzhugdzhur-Stanovoy fold belt: Formation and transformation of the continental crust in the early precambrian. Petrology 2004, 12, 211-226.

78. Larin, A.M.; Kotov, A.B.; Velikoslavinskii, S.D.; Sal'nikova, E.B.; Kovach, V.P. Early precambrian A-granitoids in the Aldan Shield and adjacent mobile belts: Sources and geodynamic environments. Petrology 2012, 20, 218-239. [CrossRef]

79. Velikoslavinskii, S.D.; Kotov, A.B.; Tolmacheva, E.V.; Sal'nikova, E.B.; Kovach, V.P.; Larin, A.M. Early Precambrian granite-gneiss complexes in the Central Aldan Shield. Petrology 2011, 19, 382-398. [CrossRef]

80. Glebovitsky, V.A.; Sedova, I.S.; Matukov, D.I.; Presnyakov, S.L.; Berezhnaya, N.G.; Tolmacheva, E.V.; Samorukova, L.M.; Sergeev, S.A. Age of the Stanovoy Complex of east Siberia: Evidence from SHRIMP II ion microprobe data. Dokl. Earth Sci. 2007, 412, 35-38. [CrossRef]

81. Donskaya, T.V. Early Protherozoic Granitoid Magmatism of the Siberian Craton. Ph.D. Thesis, (Dissertations on competition of a scientific degree of the Doctor of Geological and Mineralogical Sciences). Institute of the Earth's crust of the Siberian Branch of the Russian Academy of Sciences, Irkutsk, Russia, 2019; p. 339. (In Russian).

82. Sal'nikova, E.B.; Kotov, A.B.; Belyatskii, B.V.; Yakovleva, S.Z.; Morozova, I.M.; Berezhnaya, N.G.; Zagornaya, N.Yu. U-Pb Age of Granitoids in the Junction Zone between the Olekma Granite-Greenstone and Aldan Granulite-Gneiss Terranes. Stratigr. Geol. Correl. 1997, 13, 101-109.

83. Sal'nikova, E.B.; Kotov, A.B.; Levitskii, V.I.; Reznitskii, L.Z.; Mel'nikov, A.I.; Kozakov, I.K.; Kovach, V.P.; Barash, I.G.; Yakovleva, S.Z. Age constraints of high-temperature metamorphic events in crystalline complexes of the Irkut block, the Sharyzhalgai ledge of the Siberian platform basement: Results of the U-Pb single zircon dating. Stratigr. Geol. Correl. 2007, 15, 343-358. [CrossRef]

84. Neymark, L.A.; Larin, A.M.; Nemchin, A.A.; Ovchinnikova, G.V.; Rytsk, E.Yu. Anorogenic Nature of Magmatism in the Northern Baikal Volcanic Belt: Evidence from Geochemical, Geochronological (U-Pb), and Isotopic (Pb, Nd) Data. Petrology 1998, 6, 124-148.

85. Kotov, A.B.; Kovach, V.P.; Sal'nikova, E.B.; Glebovitskii, V.A.; Yakovleva, S.Z.; Berezhnaya, N.G.; Myskova, T.A. Stages of Continental Growth in the Central Part of the Aldan Granulite-Gneissic Area: U-Pb and Sm-Nd Isotope Data on Granitoids. Petrologiya 1995, 3, 99-110.

86. Kotov, A.B.; Sal'nikova, E.B.; Larin, A.M.; Kovach, V.P.; Savatenkov, V.M.; Yakovleva, S.Z.; Berezhnaya, N.G.; Plotkina, Yu.V. Early Proterozoic Granitoids in the Junction Zone of the Olekma Granite-Greenstone Belt and the Aldan Granulite-Gneiss Terrane, Aldan Shield: Age, Sources, and Geodynamic Environments. Petrology 2004, 12, 37-55. 
87. Kotov, A.B.; Vladykin, N.V.; Larin, A.M.; Gladkochub, D.P.; Salnikova, E.B.; Sklyarov, E.V.; Tolmacheva, E.V.; Donskaya, T.V.; Velikoslavinsky, S.D.; Yakovleva, S.Z. New data on the age of ore formation in the unique Katugin rare-metal deposit (Aldan Shield). Dokl. Earth Sci. 2015, 463, 663-667. [CrossRef]

88. Kotov, A.B.; Salnikova, E.B.; Kovach, V.P.; Velikoslavinsky, S.D.; Sklyarov, E.V.; Gladkochub, D.P.; Larin, A.M.; Tolmacheva, E.V.; Fedoseenko, A.M.; Plotkina, Yu.V. The Younger Age Limit of Metasedimentary Protolith Formation of the Lower Part of the Udokan Group Rocks (Aldan Shield). Dokl. Earth Sci. 2018, 479, 415-419. [CrossRef]

89. Rosen, O.M. The Siberian Craton: Tectonic Zoning and Stages of Evolution. Geotectonics 2003, 37, 175-192.

90. Velikoslavinskii, S.D.; Kotov, A.B.; Sal'nikova, E.B.; Larin, A.M.; Sorokin, A.A.; Sorokin, A.P.; Kovach, V.P.; Tolmacheva, E.V.; Gorokhovskii, B.M. Age of Ilikan Sequence from the Stanovoi complex of the Dzhugdzhur-Stanovoi superterrane, Central-Asian Fold belt. Dokl. Earth Sci. 2011, 438, 612-616. [CrossRef]

91. Donskaya, T.V.; Gladkochub, D.P.; Mazukabzov, A.M.; Presnyakov, S.L.; Bayanova, T.B. Paleoproterozoic granitoids of the Chuya and Kutima complexes (southern Siberian craton): Age, petrogenesis, and geodynamic setting. Russ. Geol. Geophys. 2013, 54, 283-296. [CrossRef]

92. Donskaya, T.V.; Gladkochub, D.P.; Mazukabzov, A.M.; Lepekhina, E.N. Age and sources of the Paleoproterozoic premetamorphic granitoids of the Goloustnaya block of the Siberian craton: Geodynamic applications. Petrology 2016, 24, 543-561. [CrossRef]

93. Donskaya, T.V.; Mazukabzov, A.M.; Gladkochub, D.P. Petrogenesis and structural position of the Early Proterozoic charnockites of the Tatarnikovsky massif in the South Siberian post-collisional magmatic belt of the Siberian craton. Geodyn. Tectonophys. 2018, 9, 391-412. [CrossRef]

94. Donskaya, T.V.; Gladkochub, D.P.; Mazukabzov, A.M. Early Proterozoic granitoids of the Olenek complex (northern Siberian craton): Petrogenesis and geodynamic setting. Russ. Geol. Geophys. 2018, 59, $226-237$. [CrossRef]

95. Donskaya, T.V.; Gladkochub, D.P.; Sklyarov, E.V.; Kotov, A.B.; Larin, A.M.; Starikova, A.E.; Mazukabzov, A.M.; Tolmacheva, E.V.; Velikoslavinskii, S.D. Genesis of the Paleoproterozoic Rare-Metal Granites of the Katugin Massif. Petrology 2018, 26, 47-64. [CrossRef]

96. Gavrikova, S.N.; Nikolaeva, L.L.; Galanin, A.V. Early Precambrian of the Southern Part of the Stanovoi Fold Area. Nedra Mosc. 1991, 171. (In Russian)

97. Buchko, I.V.; Sorokin, A.A.; Sal'nikova, E.B.; Kotov, A.B.; Larin, A.M.; Sorokin, A.P.; Velikoslavinskii, S.D.; Yakovleva, S.Z. Age and tectonic setting of the Kengurak-Sergachi gabbro-anorthosite massif (the Selenga-Stanovoi superterrane, southern frame of the Siberian craton). Stratigr. Geol. Correl. 2008, 16, 349-359. [CrossRef]

98. Nekrasov, G.E.; Rodionov, N.V.; Berezhnaya, N.G.; Sergeev, S.A.; Ruzhentsev, S.V.; Minina, O.R.; Golionko, B.G. $\mathrm{U}-\mathrm{Pb}$ age of zircons from plagiogranite veins in migmatized amphibolites of the Shaman Range (Ikat-Bagdarin Zone, Vitim Highland, Transbaikal Region). Dokl. Earth Sci. 2007, 413, 160-163. [CrossRef]

99. Gordienko, I.V.; Bulgatov, A.N.; Lastochkin, N.I.; Sitnikova, V.S. Composition and U-Pb isotopic age determinations (SHRIMP-II) of the ophiolitic assemblage from the Shaman Paleospreading zone and the conditions of its formation (North Transbaikalia). Dokl. Earth Sci. 2009, 429, 1420-1425. [CrossRef]

100. Gordienko, I.V.; Bulgatov, A.N.; Ruzhentsev, S.V.; Minina, O.R.; Klimuk, V.S.; Vetluzhskikh, L.I.; Nekrasov, G.E.; Lastochkin, N.I.; Sitnikova, V.S.; Metelkin, D.V.; et al. The Late Riphean-Paleozoic history of the Uda-Vitim island-arc system in the Transbaikalian sector of the Paleoasian Ocean. Russ. Geol. Geophys. 2010, 51, 461-481. [CrossRef]

101. Nekrasov, G.E.; Ruzhentsev, S.V.; Presnyakov, S.L.; Rodionov, N.V.; Lykhin, D.A.; Golionko, B.G. U-Pb SHRIMP dating of zircons from plutonic and metamorphic rocks of the Ikat-Bagdarin and Agin zones (Transbaikalia). In Proceedings of the Scientific Conference Geodynamic Evolution of the Lithosphere of the Central Asian Mobile Belt (from Ocean to Continent), Irkutsk, Russia, 16-20 October 2006; Volume 2, pp. 58-60.

102. Gordienko, I.V. Geodynamic evolution of Late Baikalides and Paleozoids in the folded periphery of the Siberian Craton. Russ. Geol. Geophys. 2006, 47, 51-67.

103. Larin, A.M.; Kotov, A.B.; Vladykin, N.V.; Gladkochub, D.P.; Kovach, V.P.; Sklyarov, E.V.; Donskaya, T.V.; Velikoslavinskii, S.D.; Zagornaya, N.Y.; Sotnikova, I.A. Rare metal granites of the Katugin Complex (Aldan Shield): Sources and geodynamic formation settings. Dokl. Earth Sci. 2015, 464, 889-893. [CrossRef] 
104. Tsygankov, A.A.; Matukov, D.I.; Berezhnaya, N.G.; Larionov, A.N.; Posokhov, V.F.; Tsyrenov, B.T.; Khromov, A.A.; Sergeev, S.A. Late Paleozoic granitods of the Western Transbaikalia: Magma sources and stages of formation. Russ. Geol. Geophys. 2007, 48, 120-140. [CrossRef]

105. Tsygankov, A.A. Late Paleozoic granitoids in Western Transbaikalia: Sequence of formation, sources of magmas, and geodynamics. Russ. Geol. Geophys. 2014, 55, 153-176. [CrossRef]

106. Kovach, V.P.; Sal'nikova, E.B.; Rytsk, E.Yu.; Yarmolyuk, V.V.; Kotov, A.B.; Anisimova, I.V.; Yakovleva, S.Z.; Fedoseenko, A.M.; Plotkina, Yu.V. The time length of formation of the Angara-Vitim batholite: Results of U-Pb geochronological studies. Dokl. Earth Sci. 2012, 444, 553-558. [CrossRef]

107. Khanchuk, A.I. Geodynamics, Magmatism, and Metallogeny of Eastern Russia, 1st ed.; Dal'nauka: Vladivostok, Russia, 2006; p. 572. (In Russian)

108. Bhatia, M.R. Plate tectonics and geochemical composition of sandstone. J. Geol. 1983, 91, 611-627. [CrossRef]

109. Roser, B.D.; Korsch, R.J. Provenance signatures of sandstone-mudstone suites determinate using discriminant function analysis of major-element data. Chem. Geol. 1988, 67, 119-139. [CrossRef]

110. McLennan, S.M.; Hemming, S.; McDanniel, D.K.; Hanson, G.N. Geochemical approaches to sedimentation, provenance, and tectonics. In Controlling the Composition of Clastic Sediments; Special Paper of the Geological Society of America; Johnsson, M.J., Basu, A., Eds.; Geological Society of America: Boulder, CO, USA, 1993; Volume 285, pp. 21-40.

111. Kroonenberg, S.B. Effects of provenance, sorting and weathering on the geochemistry of fluvial sands from different tectonic and climatic environments. In Program 29th International Geological Congress; Part, A., Nishiyama, T., Fisher, G.W., Kumon, F., Yu, K.M., Watanbe, Y., Motamed, A., Eds.; VSP: Utrecht, The Netherlands, 1994.

112. Bhatia, M.R.; Crook, K.A.W. Trace element characteristics of graywackes and tectonic setting discrimination of sedimentary basins. Contrib. Mineral. Petrol. 1986, 92, 181-193. [CrossRef]

(C) 2020 by the authors. Licensee MDPI, Basel, Switzerland. This article is an open access article distributed under the terms and conditions of the Creative Commons Attribution (CC BY) license (http://creativecommons.org/licenses/by/4.0/). 